Article

\title{
Trends and Exceptions in the Interaction of Hydroxamic Acid Derivatives of Common Di- and Tripeptides with Some 3d and 4d Metal Ions in Aqueous Solution
}

\author{
András Ozsváth ${ }^{1}$, Linda Bíró ${ }^{1}$, Eszter Márta Nagy ${ }^{1}$, Péter Buglyó ${ }^{1}$, Daniele Sanna ${ }^{2}{ }^{\circledR}$ and \\ Etelka Farkas 1,*iD \\ 1 Department of Inorganic and Analytical Chemistry, University of Debrecen, Egyetem tér 1, H-4032 Debrecen, \\ Hungary; ozsvath.andras@science.unideb.hu (A.O.); linda.biro@science.unideb.hu (L.B.); \\ neszma@hotmail.com (E.M.N.); buglyo@science.unideb.hu (P.B.) \\ 2 Istituto CNR di Chimica Biomolecolare, Trav. La Crucca 3, I-07040 Sassari, Italy; Daniele.Sanna@cnr.it \\ * Correspondence: efarkas@science.unideb.hu; Tel.: +36-52-512-900
}

Academic Editors: Francesco Crea and Alberto Pettignano

Received: 9 October 2019; Accepted: 30 October 2019; Published: 31 October 2019

\begin{abstract}
By using various techniques (pH-potentiometry, UV-Visible spectrophotometry, ${ }^{1} \mathrm{H}$ and ${ }^{17} \mathrm{O}-\mathrm{NMR}, \mathrm{EPR}, \mathrm{ESI}-\mathrm{MS}$ ), first time in the literature, solution equilibrium study has been performed on complexes of dipeptide and tripeptide hydroxamic acids-AlaAlaNHOH, AlaAlaN(Me)OH, AlaGlyGlyNHOH, and AlaGlyGlyN(Me)OH-with 4d metals: the essential Mo(VI) and two half-sandwich type cations, $\left[\left(\eta^{6}-p-c y m\right) \mathrm{Ru}\left(\mathrm{H}_{2} \mathrm{O}\right)_{3}\right]^{2+}$ as well as $\left[\left(\eta^{5}-\mathrm{Cp}^{*}\right) \mathrm{Rh}\left(\mathrm{H}_{2} \mathrm{O}\right)_{3}\right]^{2+}$, the latter two having potential importance in cancer therapy. The tripeptide derivatives have also been studied with some biologically important 3d metals, such as $\mathrm{Fe}(\mathrm{III}), \mathrm{Ni}(\mathrm{II}), \mathrm{Cu}(\mathrm{II})$, and $\mathrm{Zn}$ (II), in order to compare these new results with the corresponding previously obtained ones on dipeptide hydroxamic acids. Based on the outcomes, the effects of the type of metal ions, the coordination number, the number and types of donor atoms, and their relative positions to each other on the complexation have been evaluated in the present work. We hope that these collected results might be used when a new peptide-based hydroxamic acid molecule is planned with some purpose, e.g., to develop a potential metalloenzyme inhibitor.
\end{abstract}

Keywords: peptide hydroxamic acids; solution equilibrium; metal complexation; $\mathrm{Ru}(\mathrm{II})-$, $\mathrm{Rh}(\mathrm{III})$-based half-sandwich complexes; Mo(VI) complexes

\section{Introduction}

Hydroxamic acids containing one or more weak acidic function $(\mathrm{s})-\mathrm{C}(\mathrm{O}) \mathrm{N}(\mathrm{R}) \mathrm{OH}(\mathrm{R}=\mathrm{H}$ in primary, alkyl or aryl moiety in secondary derivatives) [1,2] are an important class of organic molecules with a huge number of biological activities, including the well-known, crucial role of the hydroxamate-based natural siderophores in the microbial iron uptake [3] or antifungal, antimalarial, metalloenzyme inhibitory effects $[4,5]$. Some derivatives may also behave as NO donors under certain conditions [6]. In some part, these diverse and important effects also depend on the significant H-bonding ability [7] or redox behaviour of this moiety [8,9], but predominantly, the rely on its strong chelating ability $[1,2]$. Consequently, investigation of complexation between metal ions and hydroxamic acids is permanently the focus of interest. The most typical coordination mode of a hydroxamate function involves chelation via deprotonated hydroxyl and carbonyl oxygen atoms providing a five-membered $(\mathrm{O}, \mathrm{O})$ chelate, which can be hydroxamato, if the function is mono-deprotonated, and hydroximato, if it is doubly-deprotonated. The latter type of chelate can only be formed with primary derivatives. A few examples have also been known for other modes of interactions [8,9]. Significantly increased versatility 
of the potential coordination modes exists in the presence of additional donors, such as amino or/and peptide groups in a hydroxamic derivative. This is clearly demonstrated by numerous results collected mostly on metal complexes of aminohydroxamic acids [10-16]. Significantly, increased interest toward the metal complexes of aminohydroxamic acids have been realised following the first publication on a pentanuclear $\beta$-alaninehydroxamate-based $\mathrm{Cu}(\mathrm{II})$-containing metallacrown complex both in solution and in the solid state [14] and the discovery of numerous and diverse possibilities of applications of such compounds $[15,16]$. Peptide hydroxamic acids, however, despite the special interest in them e.g., to develop substrate-based metalloenzyme inhibitors [5], have very rarely been involved in solution studies [17-21]. Moreover, most of the results relate to complexes with $3 d^{5-10}$ transition metal ions and only a few with $4 \mathrm{~d}$ metals [21]. Following our solution equilibrium work done ca. thirty years ago on the complexation of ProLeuNHOH and ProLeuGlyNHOH with several 3d metals [17], we performed a detailed equilibrium study on complexation of a few simple dipeptide hydroxamic acids with Fe(III), $\mathrm{Al}(\mathrm{III}), \mathrm{Ni}(\mathrm{II}), \mathrm{Cu}(\mathrm{II})$, and $\mathrm{Zn}(\mathrm{II})$. The special interest in ProLeuGlyNHOH is due to the fact that human collagenase (a zinc(II)-containing metalloezyme) was isolated by means of an affinity column prepared with this tripeptide hydroxamic acid [22]. The obtained results showed the exclusive formation of $(\mathrm{O}, \mathrm{O})$ chelated hydroxamate species with the hard $\mathrm{Fe}(\mathrm{III})$ and $\mathrm{Al}(\mathrm{III})$ ions, while $(\mathrm{O}, \mathrm{O})$ and $\left(\mathrm{NH}_{2}, \mathrm{CO}\right)$ chelated linkage isomers with $\mathrm{Zn}(\mathrm{II})$. These three metal ions were found not to induce deprotonation and parallel coordination of the peptide amide-N or primary hydroxamate-N, the processes of which, however, became deterministic with $\mathrm{Cu}(\mathrm{II})$ and especially with $\mathrm{Ni}(\mathrm{II})[19,20]$.

Out of the platinum group metals, only a recent publication from our lab discusses solution results on the rather complicated $\mathrm{Pd}(\mathrm{II})-\mathrm{AlaAlaNHOH},-\mathrm{AlaAlaN}(\mathrm{Me}) \mathrm{OH},-\mathrm{AlaGlyGlyNHOH}$, and -AlaGlyGlyN(Me)OH systems. In these systems, complexation and metal ion-induced hydrolytic and redox processes were found in a ligand-dependent extent [21]. No other metal from this group has previously been involved in investigations with peptide hydroxamic acids. The lack of interest came most probably from the high hydrolytic ability of these metals, as well as the inertness of their complexes. However, the intensive interest in relation to cancer therapy on numerous complexes with platinum group metals, together with the well-known fact that inertness of a complex is determined not only by the character of the metal ion but also by the mobility of the coordinated ligands, initiated studies in the past several years. For example, solution equilibrium measurements were successfully performed with half-sandwich type platinum group metal cations, including ruthenium and rhodium, in which an arene (benzene or its derivative such as 1-methyl-4-isopropylbenzene $(p$-cym)) or arenyl (pentamethyl-cyclopentadienyl $\left(C \mathrm{p}^{*}\right)$ ) replaces three of the six solvent molecules, and complexation reactions can occur at the remaining three sites $[23,24]$. Recently, several types of hydroxamate-based ligands, including aminohydroxamic acids, have already been involved in solution equilibrium studies with these half-sandwich type cations [12,13], but only peptide hydroxamic acids are studied in the present work.

Likewise, according to the best of our knowledge, no publication can be found for complexes of peptide hydroxamic acids with molybdenum, despite the fact that this is an essential metal (the only one out of the $4 \mathrm{~d}$ metals) and the biological activities of more than 50 enzymes are known to rely on it $[25,26]$. Again, the very high tendency of this metal for hydrolysis is one of the main reasons for the lack of investigations. Moreover, the stable form of Mo(VI) does not exist as an aqua-ion at all; only $\mathrm{MoO}_{4}{ }^{2-}$ ion including various protonated forms of this oxido anion or its polymeric units exist [11].

As a continuation of our previous solution equilibrium work in this subject, in the present work, we have investigated the interaction of dipeptide and tripeptide hydroxamic acids, AlaAlaNHOH, AlaAlaN(Me)OH, AlaGlyGlyNHOH, and AlaGlyGlyN(Me)OH (see their structures in Scheme 1) with $4 \mathrm{~d}$ metals, Mo(VI), and half-sandwich type cations of ruthenium(II), as well as rhodium(III), $\left[\left(\eta^{6}-p \text {-cym }\right) \mathrm{Ru}\left(\mathrm{H}_{2} \mathrm{O}\right)_{3}\right]^{2+}$, or $\left[\left(\eta^{5}-\mathrm{Cp}^{*}\right) \mathrm{Rh}\left(\mathrm{H}_{2} \mathrm{O}\right)_{3}\right]^{2+}$, respectively. To provide us with the possibility for a comparison between the results collected with $3 \mathrm{~d}$ metals and $4 \mathrm{~d}$ ones, investigation of the complexation with the (previously not studied) above tripeptide derivatives and metal ions as Fe(III), $\mathrm{Ni}(\mathrm{II}), \mathrm{Cu}(\mathrm{II})$, and $\mathrm{Zn}(\mathrm{II})$ was also performed. 
<smiles>CC(N)C(=O)NCC(=O)NCC(=O)NO</smiles>

H-AlaGlyGlyNHOH ${ }^{+}$<smiles>CC(N)C(=O)NC(C)C(=O)NO</smiles>

H-AlaAlaNHOH ${ }^{+}$<smiles>CC(N)C(=O)NCC(=O)NCC(=O)N(C)O</smiles>

H-AlaGlyGlyN(Me)OH ${ }^{+}$<smiles>CC(N)C(=O)NC(C)C(=O)N(C)O</smiles>

H-AlaAlaN(Me)OH ${ }^{+}$

Scheme 1. Structures of the fully protonated ligands $\left(\mathrm{H}_{2} \mathrm{~L}^{+}\right)$.

\section{Results}

\subsection{Protonation Equilibria of the Investigated Peptide Hydroxamic Acids}

Each of the completely protonated form of the ligands have two deprotonation processes in the measurable $\mathrm{pH}$-range; the calculated dissociation constants are presented in Table 1 . Literature data could be found for the investigated dipeptide derivatives only in the presence of $\mathrm{KCl}$, and those are in perfect agreement with the corresponding ones in Table $1[19,20]$. As can be seen in Table 1, there is practically no difference between the corresponding values of the di- and tripeptide derivatives determined either in the presence of $\mathrm{KCl}$ or $\mathrm{KNO}_{3}$, but in accordance with earlier results, the dissociation constants for the secondary hydroxamic acids are $0.1-0.3 \mathrm{log}$ unit smaller than those of the corresponding primary ones. This difference originates from the more enhanced delocalisation along the hydroxamate anions in the presence of an electron releasing alkyl group [20]. It is also known that the dissociation processes of the ammonium and hydroxamic groups considerably overlap each other [19]. Consequently, the values in Table 1 are macroconstants and cannot be ascribed unambiguously to the individual moieties. In one of our previous works, the dissociation microconstants were determined for the binding isomers of AlaAlaNHOH, and they supported the somewhat higher acidity of the ammonium group [19]. Since no significant difference can be assumed between the basicities of the investigated peptide hydroxamic acids, determination of dissociation microconstants for the additional ligands was beyond the scope of this work.

Table 1. Stepwise dissociation constants $(\mathrm{pK})$ of the ligands at $25.0^{\circ} \mathrm{C}, \mathrm{I}=0.20 \mathrm{M}\left(\mathrm{KCl} \text { or } \mathrm{KNO}_{3}\right)^{*}$

\begin{tabular}{|c|c|c|c|c|}
\hline \multirow[b]{2}{*}{ Ligand } & \multicolumn{2}{|c|}{$\mathrm{I}=0.20 \mathrm{M} \mathrm{KCl}$} & \multicolumn{2}{|c|}{$\mathrm{I}=0.20 \mathrm{M} \mathrm{KNO}_{3}$} \\
\hline & $\mathrm{p} K_{1}$ & $\mathrm{p} K_{2}$ & $\mathrm{p} K_{1}$ & $\mathrm{p} K_{2}$ \\
\hline H-AlaAlaNHOH ${ }^{+}$ & $7.66^{1}$ & $8.88^{1}$ & $7.77(1)$ & $8.89(1)$ \\
\hline H-AlaAlaN(Me)OH ${ }^{+}$ & $7.74^{2}$ & $8.74^{2}$ & $7.77(1)$ & $8.70(1)$ \\
\hline H-AlaGlyGlyNHOH ${ }^{+}$ & $7.71(1)$ & $8.82(1)$ & 7.74(1) & $8.82(1)$ \\
\hline H-AlaGlyGlyN(Me)OH ${ }^{+}$ & $7.66(1)$ & $8.63(1)$ & $7.69(1)$ & $8.57(1)$ \\
\hline
\end{tabular}

* $3 \sigma$ standard deviations are in parentheses; ${ }^{1}$ taken from [19]; ${ }^{2}$ taken from [20].

\subsection{Complexation of AlaGlyGlyNHOH and AlaGlyGlyN(Me)OH with Selected 3d Ions-Fe(III), Ni(II), $\mathrm{Cu}(\mathrm{II})$, and $\mathrm{Zn}(\mathrm{II})$}

Although the present solution equilibrium work has focused on the complexation of hydroxamic acid derivatives of common di- and tripeptides with the biologically important $4 \mathrm{~d}$ metals Mo(VI), $\mathrm{Ru}(\mathrm{II})$, and $\mathrm{Rh}(\mathrm{III})$, a comparison between the results collected on complexes with the selected $3 \mathrm{~d}$ and $4 \mathrm{~d}$ metals has also been our aim.

Since detailed solution equilibrium results have been previously published only on the Fe(III), $\mathrm{Ni}(\mathrm{II}), \mathrm{Cu}(\mathrm{II})$, and $\mathrm{Zn}(\mathrm{II})$ complexes of the two dipeptide hydroxamic acids AlaAlaNHOH and 
AlaAlaN(Me)OH $[19,20]$, the present paper shortly discusses the results obtained for the two tripeptide hydroxamic acids AlaGlyGlyNHOH and AlaGlyGlyN(Me)OH.

The experimental results were collected on the Fe(III), Ni(II), $\mathrm{Cu}(\mathrm{II})$, and $\mathrm{Zn}$ (II) complexes of AlaGlyGlyNHOH and AlaGlyGlyN(Me)OH by the methods and under the conditions detailed in the Experimental section. The equilibrium models and logarithmic overall stability constants presented in Table 2 were determined by $\mathrm{pH}$-potentiometry, except for the complexes with Fe(III), where combination of $\mathrm{pH}$-metry and spectrophotometry provided the possibility for calculation of stability constants. The reason behind is the formation of complexes with $[\mathrm{FeHL}]^{3+}$ stoichiometry below the $\mathrm{pH}$-metrically measurable $\mathrm{pH}$-range (far below $\mathrm{pH}$ 2). Their stability constants therefore were determined by fitting the spectra recorded on individual samples in the pH-range 0.7-1.6 (see Experimental part). These calculated constants were kept fixed when $\mathrm{pH}$-metric titration curves, and UV-Visible spectra registered in the whole measured $\mathrm{pH}$-range were fitted.

Table 2. Overall stability constants $(\log \beta)$ for the Fe(III), Ni(II), $\mathrm{Cu}(\mathrm{II})$, and $\mathrm{Zn}(\mathrm{II})$ complexes formed with the investigated tripeptide hydroxamic acids at $25.0^{\circ} \mathrm{C}, \mathrm{I}=0.20 \mathrm{M}(\mathrm{KCl})^{*}$.

\begin{tabular}{|c|c|c|c|c|}
\hline & AlaAlaNHOH $^{1}$ & AlaAlaN(Me)OH ${ }^{2}$ & AlaGlyGlyNHOH & AlaGlyGlyN(Me)OH \\
\hline$[\mathrm{FeHL}]^{3+}$ & $17.62^{\mathrm{a}}$ & $18.08^{a}$ & $17.74(1)^{\mathrm{a}}$ & $17.64(1)^{\mathrm{a}}$ \\
\hline$[\mathrm{FeL}]^{2+}$ & 15.09 & 14.67 & - & - \\
\hline \multirow[t]{2}{*}[\mathrm{FeH}_{2}\mathrm{L}_{2}]{$^{3+}$} & 34.57 & 33.8 & $34.02(5)$ & $33.70(7)$ \\
\hline & $34.00^{\mathrm{a}}$ & $34.71^{\mathrm{a}}$ & $34.00(2)^{\mathrm{a}}$ & $33.76(1)^{a}$ \\
\hline \multirow{2}{*}[\mathrm{FeH}_{3}\mathrm{L}_{3}]{$^{3+}$} & 49.40 & 50.01 & $48.7(2)$ & $48.97(11)$ \\
\hline & $48.61^{\mathrm{a}}$ & $49.51^{\mathrm{a}}$ & $48.55(3)^{a}$ & $48.16(2)^{a}$ \\
\hline$[\mathrm{NiHL}]^{2+}$ & 12.50 & - & $12.79(3)$ & $11.6(2)$ \\
\hline$[\mathrm{NiL}]^{+}$ & 6.30 & 6.01 & - & $5.04(7)$ \\
\hline$\left[\mathrm{NiH}_{-1} \mathrm{~L}\right]$ & -1.10 & - & - & $-3.3(1)$ \\
\hline$\left[\mathrm{NiH}_{-2} \mathrm{~L}\right]^{-}$ & -9.57 & - & $-7.44(2)$ & $-10.78(3)$ \\
\hline$\left[\mathrm{NiHL}_{2}\right]^{+}$ & - & 16.8 & - & $17.10(9)$ \\
\hline$\left[\mathrm{NiL}_{2}\right]$ & - & 9.13 & - & - \\
\hline$[\mathrm{CuHL}]^{2+}$ & 14.70 & 15.02 & $14.45(7)$ & $14.66(2)$ \\
\hline$\left[\mathrm{Cu}_{2} \mathrm{~L}_{2}\right]^{2+}$ & 23.20 & - & - & - \\
\hline$\left[\mathrm{CuH}_{-1} \mathrm{~L}\right]$ & 4.43 & 3.04 & - & $3.52(2)$ \\
\hline$\left[\mathrm{CuH}_{-2} \mathrm{~L}\right]^{-}$ & -5.24 & -6.63 & $-5.38(5)$ & $-5.28(2)$ \\
\hline$\left[\mathrm{CuH}_{2} \mathrm{~L}_{2}\right]^{2+}$ & - & 29.17 & - & $27.6(2)$ \\
\hline$\left[\mathrm{CuHL}_{2}\right]^{+}$ & - & 22.3 & - & $22.23(9)$ \\
\hline$\left[\mathrm{CuL}_{2}\right]$ & - & 14.8 & - & $14.8(1)$ \\
\hline$\left[\mathrm{CuH}_{-1} \mathrm{~L}_{2}\right]^{-}$ & - & 6.3 & - & - \\
\hline$\left[\mathrm{Cu}_{3} \mathrm{H}_{-4} \mathrm{~L}_{2}\right]$ & 5.89 & - & - & - \\
\hline$\left[\mathrm{Cu}_{3} \mathrm{H}_{-5} \mathrm{~L}_{2}\right]^{-}$ & -3.56 & - & - & - \\
\hline$\left[\mathrm{Cu}_{3} \mathrm{H}_{-6} \mathrm{~L}_{2}\right]^{2-}$ & -14.28 & - & - & - \\
\hline$[\mathrm{ZnHL}]^{2+}$ & 12.35 & 12.00 & $12.47(2)$ & $11.92(2)$ \\
\hline$[\mathrm{ZnL}]^{+}$ & 5.64 & 5.11 & $5.07(6)$ & $4.55(2)$ \\
\hline$\left[\mathrm{ZnH}_{-1} \mathrm{~L}\right]$ & -2.58 & -3.23 & $-3.18(2)$ & $-3.46(3)$ \\
\hline$\left[\mathrm{ZnHL}_{2}\right]^{+}$ & 17.52 & 17.12 & - & - \\
\hline
\end{tabular}

* $3 \sigma$ standard deviations are in parentheses; ${ }^{\text {a }}$ Determined from UV-Vis data; ${ }^{1}$ taken from reference [19]; ${ }^{2}$ taken from reference [20].

For easier comparison, Table 2 also contains the previously published data for the complexes of dipeptide derivatives determined under the same conditions as used in the present study.

As shown in Table 2, there is a good agreement between both the equilibrium models and numerical values of the constants determined by $\mathrm{pH}$-metry and spectrophotometry for the mono-, bis- and tris-complexes of primary and secondary di- and tripeptide derivatives with Fe(III). The only difference between the models is that the $[\mathrm{FeL}]^{2+}$ complex-what was found with the dipeptide hydroxamic acids and was assumed to be a mixed hydroxido species-was not formed in measurable concentration with the two tripeptide derivatives. Based on the almost perfect agreement, the same coordination modes are assumed with the tripeptide derivatives as it was found with the dipeptide-based counterparts [19,20]: 
coordination of the hydroxamate oxygens while the non-coordinating amino moiety is protonated. The UV-Visible spectra showing the well-known charge-transfer (C.T.) bands in both Fe(III)-tripeptide hydroxamic acid systems, clearly support this assumption. The registered spectra in the $\mathrm{pH}$-range ca. 0.7-1.6 (where the [FeHL] ${ }^{3+}$ is formed) are characteristic for an Fe(III)-monohydroxamato complex $\left(\lambda_{\max }=510 \mathrm{~nm}\right)$. Upon increasing the $\mathrm{pH}$, a decrease of the $\lambda_{\max }$ down to $460 \mathrm{~nm}$ in a second stepwise process by $\mathrm{pH}$ ca. 3-3.5 occurs (this process belongs to the formation of the bis-hydroxamato species $\left.\left[\mathrm{Fe}(\mathrm{HL})_{2}\right]^{3+}\right)$, while as a result of a third process, the tris-hydroxamato species $\left[\mathrm{Fe}(\mathrm{HL})_{3}\right]^{3+}$ is formed by ca. $\mathrm{pH} 6.5$ with a characteristic $\lambda_{\max }=420-425 \mathrm{~nm}$. Above $\mathrm{pH}$ ca. 6.5 , the formation of mixed hydroxido species was indicated to start by the spectra even at 1:5 metal to ligand ratio in both systems.

$\mathrm{Zn}(\mathrm{II})$ is the other metal ion, with which both the equilibrium models and stability constants are quite similar in all of the four systems. The only exception in the models is that bis-complex was found to form under our conditions with the dipeptide derivatives but not with the two tripeptide hydroxamic acids, most probably because of sterical reasons. All these findings suggest that $\mathrm{Zn}$ (II) behaves very similarly toward the two tripeptide-based ligands, as was previously supported by ${ }^{1} \mathrm{H}-\mathrm{NMR}$ results for the complexes of AlaAlaNHOH [19] and AlaAlaN(Me)OH [20]. Consequently, AlaGlyGlyNHOH and AlaGlyGlyN(Me)OH are assumed to form moderate stability binding isomers with $\mathrm{Zn}(\mathrm{II})$, in which coordination occurs via either the five-membered $(\mathrm{O}, \mathrm{O})_{\text {hydr }}$ chelate or the five-membered $\left(\mathrm{NH}_{2}, \mathrm{CO}\right)$ chelate. Only one of these two possible chelates exists in $[\mathrm{ZnHL}]^{2+}$ (which starts to form at $\mathrm{pH}$ ca. 4.8-5), while the other moiety is still in protonated, non-coordinated form. Upon increasing the $\mathrm{pH}$, the formation of $[\mathrm{ZnL}]^{+}$, followed by $\left[\mathrm{ZnH}_{-1} \mathrm{~L}\right]$, was found. They are most probably mixed hydroxido species and in the $\mathrm{pH}$-range where the free ligand itself deprotonates (above $\mathrm{pH} 7$ ) and the dissociation of the non-coordinating moiety also occurs. As in the case of Fe(III), there is no indication for the $\mathrm{Zn}$ (II)-induced deprotonation and coordination of peptide amide function in any of the investigated systems.

The situation is completely different with $\mathrm{Ni}(\mathrm{II})$ and $\mathrm{Cu}(\mathrm{II})$, in which metal ions accept $\mathrm{N}$-donor ligands readily. At the same time, the different number and, in some part, type of the N-donors in the studied ligands results in different coordinating behaviour of them toward these metal ions: AlaAlaNHOH contains $3 \mathrm{~N}\left(\mathrm{NH}_{2}, \mathrm{~N}_{\text {amide }}, \mathrm{N}_{\text {hydr. }}\right)$, AlaAlaN(Me)OH involves $2 \mathrm{~N}\left(\mathrm{NH}_{2}, \mathrm{~N}_{\text {amide }}\right)$ donor atoms, there are $4 \mathrm{~N}$ donors in the tripeptide derivative AlaGlyGlyNHOH $\left(\mathrm{NH}_{2}, 2 \times \mathrm{N}_{\text {amide }}, \mathrm{N}_{\text {hydr. }}\right)$, while $3 \mathrm{~N}$ in its secondary counterpart, AlaGlyGlyN(Me)OH $\left(\mathrm{NH}_{2}, 2 \times \mathrm{N}_{\text {amide }}\right)$. The significant role of the amino-N, amide- $\mathrm{N}$ and for the primary hydroxamic derivatives, hydroxamate- $\mathrm{N}$ in the $\mathrm{Ni}$ (II)- and $\mathrm{Cu}(\mathrm{II})-\mathrm{AlaAlaNHOH}$ and -AlaAlaN(Me)OH systems was discussed in our previous papers [19,20]. In the present work, both AlaGlyGlyNHOH and AlaGlyGlyN(Me)OH were found to react with $\mathrm{Ni}$ (II) above $\mathrm{pH}$ ca. 4. The first species, [NiHL], are formed in low extent below $\mathrm{pH}$ ca. 6, in which the ligands are assumed to coordinate in a similar manner as it was supported with the dipeptide derivative, either via five-membered $\left(\mathrm{NH}_{2}, \mathrm{CO}\right)$ or $(\mathrm{O}, \mathrm{O})_{\text {hydr. }}$. The colour of the samples turned to yellow above $\mathrm{pH}$ ca. 6 with the primary derivative and above $\mathrm{pH}$ ca. 7 with its secondary counterpart. This latter $\mathrm{pH}$ is much lower than the value, where the color turned to yellow in the Ni(II)-AlaAlaN(Me)OH system, above $\mathrm{pH} 9$ [20]. Above these $\mathrm{pH}$ values, the spectra registered in both systems are characteristic for square planar Ni(II) complexes (Figure 1a,b).

Although the most probable cooperative processes with the primary ligand were too slow to allow determination of stability constants for the stepwise equilibria, there is no doubt that four equivalents of base are consumed by the end of the titrations, up to $\mathrm{pH}$ ca. 11 . The calculated stability constant for $\left[\mathrm{NiH}_{-2} \mathrm{~L}^{-}\right.$ formed is shown in Table 2. The two dissociable protons of the ligand consume two equivalents of base, while the additional two react with the protons from the two peptide moieties. Consequently, $\left[\mathrm{NiH}_{-2} \mathrm{~L}^{-}\right.$, which was found to be a mixed hydroxido complex with AlaAlaNHOH [19], is a 4N-coordinated complex with AlaGlyGlyNHOH, and the coordinating donor set is $\left(\mathrm{NH}_{2}, \mathrm{~N}_{\text {amide, }}, \mathrm{N}_{\text {amide, }}, \mathrm{N}_{\text {hydr }}\right)$. This assumption is further supported by the UV-Visible parameters $\left(\lambda_{\max }=400 \mathrm{~nm}, \varepsilon \mathrm{ca} .200 \mathrm{M}^{-1} \mathrm{~cm}^{-1}\right)$, which are similar to those obtained previously for the $4 \mathrm{~N}$-coordinated complex in the Ni(II)-ProLeuGlyNHOH system [17]. 


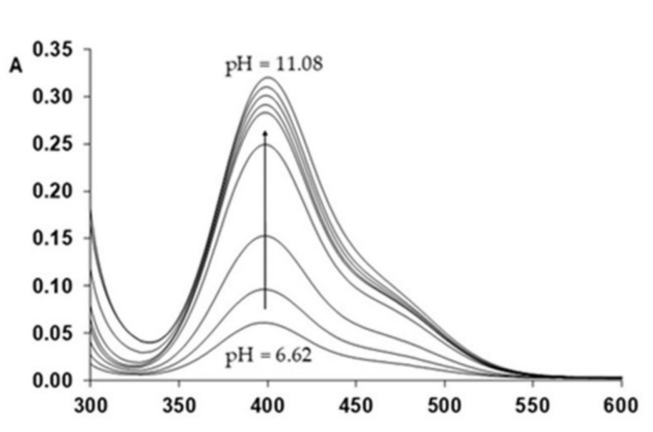

(a)

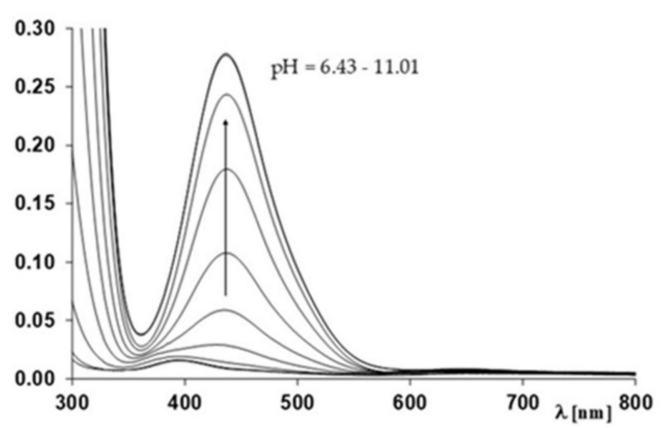

(b)

Figure 1. UV-Visible spectra recorded at different $\mathrm{pH}$ values for the (a) $\mathrm{Ni}(\mathrm{II})-\mathrm{AlaGlyGlyNHOH}$ and (b) $\mathrm{Ni}(\mathrm{II})-\mathrm{AlaGlyGlyN}(\mathrm{Me}) \mathrm{OH}$ systems at 1:1 ratio $\left(\mathrm{c}_{\mathrm{Ni}(\mathrm{II})}=1.5 \mathrm{mM}\right)$.

Like in the case of the primary counterpart, four equivalents of base were altogether consumed during the titration of $\mathrm{Ni}(\mathrm{II})-\mathrm{AlaGlyGlyN}(\mathrm{Me}) \mathrm{OH}$ samples as well. There is no doubt that the final species, $\left[\mathrm{NiH}_{-2} \mathrm{~L}\right]^{-}$, is a planar complex in this case, in which the metal ion is coordinated by the $\left(\mathrm{NH}_{2}, \mathrm{~N}_{\text {amide }}, \mathrm{N}_{\text {amide }}, \mathrm{O}_{\text {hydr }}\right)$ donor set. With this secondary tripeptide hydroxamic acid, however, the processes were fast enough to allow the calculation of stability constants for the intermediate species. At the same time, if the stepwise dissociation constants for the complexes using the corresponding overall stability constants in Table 2 are calculated, an irregular trend is found: $\mathrm{pK}_{\mathrm{NiL}}$ is higher than $\mathrm{pK}_{\mathrm{NiH}-1 \mathrm{~L}},(5.04-(-3.3)=8.34$ and $-3.3-(-10.78)=7.48$, respectively $)$, showing cooperativity of the processes in this system, too. With AlaGlyGlyN(Me)OH, no hydrolysis, but bis-complex formation in a small extent and in a narrow $\mathrm{pH}$-range (what was dominant with the secondary dipeptide, AlaAlaN(Me)OH [20]), was detected.

Between $\mathrm{Cu}$ (II) and the two tripeptide derivatives, complexation starts as low as $\mathrm{pH}$ ca. 2.5-3, where the competition between the proton and metal ion for the coordinating sites is very significant, as it was discussed previously [27]. An evaluation, based on this literature information allowed us to draw the conclusion that among the likely chelates $(\mathrm{O}, \mathrm{O})_{\text {hydr }}$ has the highest conditional stability under the above acidic conditions. Consequently, the hydroxamate function behaves as anchor site for the $\mathrm{Cu}$ (II) ion. In fact, this coordination mode was unambiguously supported by both the characteristic charge transfer band at $\lambda_{\max } \mathrm{ca} .370-380 \mathrm{~nm}$ and the EPR results $\left(\mathrm{g}_{\mathrm{II}}=2.345\right.$ and $2.335, \mathrm{~A}_{\text {II }}=160.5 \times 10^{-4}$ and $159.8 \times 10^{-4} \mathrm{~cm}^{-1}$ with AlaGlyGlyNHOH and AlaGlyGlyN(Me)OH, respectively) in the [CuHL] ${ }^{2+}$ formed. Despite the fact that four equivalents of base were consumed with both of the ligands by $\mathrm{pH}$ ca. 11, several experimental findings collected above $\mathrm{pH}$ ca. 4.5 in the two systems differ from each other. Namely: (1) The primary derivative was capable of binding $\mathrm{Cu}(\mathrm{II})$ excess, the secondary not. (2) Bis-complexes were less favoured with the primary ligand but were present in low concentration also with this ligand. (3) The processes were very slow above $\mathrm{pH} 5$ in the $\mathrm{Cu}(\mathrm{II})-\mathrm{AlaGlyGlyNHOH}$ system, hindering the calculation of stability constants for some of the species formed, but those were significantly faster for the $\mathrm{Cu}(\mathrm{II})-\mathrm{AlaGlyGlyN}(\mathrm{Me}) \mathrm{OH}$ system allowing calculations from the whole measured $\mathrm{pH}$-range (see Table 2). Fortunately, EPR and UV-Visible measurements provided clear support for the different complexes formed in these two systems. For illustration, some EPR spectra recorded at various $\mathrm{pH}$ values for $\mathrm{Cu}$ (II)-AlaGlyGlyNHOH and $\mathrm{Cu}(\mathrm{II})-\mathrm{AlaGlyGlyN}(\mathrm{Me}) \mathrm{OH}$ samples are shown in Figure $\mathrm{S} 1$ (a) and (b), respectively.

As Figure S1a reveals, with AlaGlyGlyNHOH in the pH-range ca. 6-7, the decreased intensity of the EPR signals supports the presence of a dinuclear species as major complex following [CuHL] ${ }^{2+}$ with hydroxamate coordination. The existence of some EPR activity indicates that no spin-crossover but weak interaction exists between the two metal ions in the dinuclear complex. The calculated EPR parameters suggest that one of the $\mathrm{Cu}(\mathrm{II})$ is coordinated by two $(\mathrm{O}, \mathrm{O})_{\text {hydr }}$ chelates $\left(\mathrm{g}_{\mathrm{II}}=2.283\right.$ and $\mathrm{A}_{\mathrm{II}}=181.7 \times 10^{-4} \mathrm{~cm}^{-1}$ ), while the other is coordinated by nitrogens. At $\mathrm{pH}=9.2$, the calculated parameters $\left(\mathrm{g}_{\mathrm{II}}=2.176\right.$ and $\left.\mathrm{A}_{\mathrm{II}}=213.4 \times 10^{-4} \mathrm{~cm}^{-1}\right)$ are in perfect agreement with those published for 
the $4 \mathrm{~N}$-coordinated complex in the $\mathrm{Cu}(\mathrm{II})-\mathrm{ProLeuGlyNHOH}$ system $\left(\mathrm{g}_{\mathrm{II}}=2.181\right.$ and $\mathrm{A}_{\mathrm{II}}=208.5 \times$ $\left.10^{-4} \mathrm{~cm}^{-1}\right)$ [17]. This suggests an $\left(\mathrm{NH}_{2}, \mathrm{~N}_{\text {amide }}, \mathrm{N}_{\text {amide, }}, \mathrm{N}_{\text {hydr }}\right)$-type coordination mode in $\left[\mathrm{CuH}_{-2} \mathrm{~L}\right]^{-}$, predominating at this $\mathrm{pH}$. Additional support for the suggested coordination mode in this complex was provided by the $\lambda_{\max }=500 \mathrm{~nm}$ of the $d-d$ band in the UV-Visible spectrum.

Interestingly, the mononuclear bis-complex, $\left[\mathrm{Cu}(\mathrm{HL})_{2}\right]^{2+}$ was found as a major species at ligand excess in the pH-range 4.7-6.5 with AlaGlyGlyN(Me)OH (see Figure S1b). The EPR parameters calculated for this complex show coordination of two hydroxamates $\left(\mathrm{g}_{\mathrm{II}}=2.283\right.$ and $\left.\mathrm{A}_{\mathrm{II}}=181.7 \times 10^{-4} \mathrm{~cm}^{-1}\right)$. In the pH-range 6.5-8.1 involvement of nitrogens in the coordination is clearly shown by the EPR spectra, but the presence of the C.T. band at $\lambda_{\max }=380 \mathrm{~nm}$ in this $\mathrm{pH}$ range proves the involvement of the hydroxamate oxygens in the coordination too. Some cooperativity of the processes in this $\mathrm{pH}$-range is indicated by the results and in $\left[\mathrm{CuH}_{-1} \mathrm{~L}\right]$, predominating at 1:1 metal ion to ligand ratio, highly distorted arrangement of the coordinated donors is shown by the appropriate EPR parameters $\left(\mathrm{g}_{\mathrm{II}}=2.172\right.$ and $\left.A_{I I}=124.3 \times 10^{-4} \mathrm{~cm}^{-1}\right)$. Tentative binding modes for this species are shown in structures I and II in Scheme 2. The combination of $g$ and A values suggests that the donor atoms involved in the metal coordination are strong donors (low g value) but the structure is very distorted (low A value); if also the $\mathrm{g}$ value was high we should think to a weak coordination [28,29]. Because we do not have a comparison with similar complexes having the same donor atoms coordinated but with a less distorted structure, we are not sure that the coordination is exactly the one that is reported as proposed structures I or II in Scheme 2. Upon increasing the $\mathrm{pH}$ further, $\left[\mathrm{CuH}_{-2} \mathrm{~L}\right]^{-}$becomes even more predominant with the $\left(\mathrm{NH}_{2}, \mathrm{~N}_{\text {amide }}, \mathrm{N}_{\text {amide}}, \mathrm{O}_{\text {hydr }}\right)$ donor set (structure III in Scheme 2).

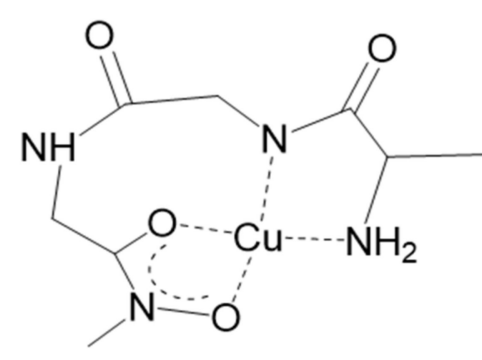

I

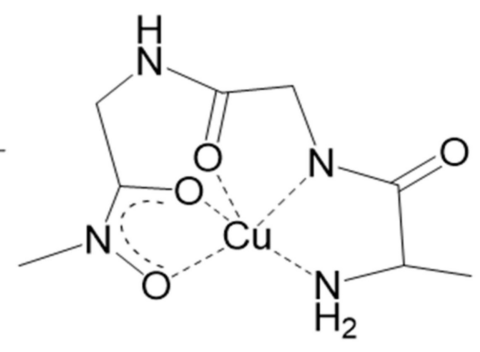

II

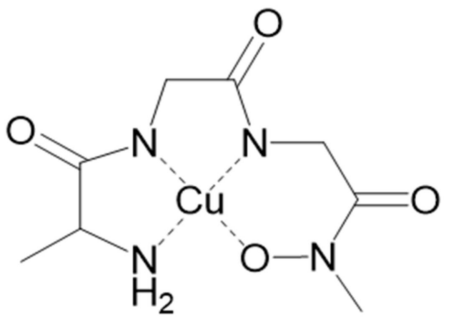

III

Scheme 2. Plausible binding modes in the complexes $\left[\mathrm{CuH}_{-1} \mathrm{~L}\right]$ (structures I and II) and the most possible mode in $\left[\mathrm{CuH}_{-2} \mathrm{~L}\right]^{-}$(structure III), $\mathrm{L}^{-}=$AlaGlyGlyN(Me)O $\mathrm{O}^{-}$.

2.3. Complexation of AlaAlaNHOH, AlaAlaN(Me)OH, AlaGlyGlyNHOH, and AlaGlyGlyN(Me)OH with the Essential 4d Ion Mo(VI)

The registered $\mathrm{pH}$-potentiometric titration curves, similarly to the few previous results on $\mathrm{Mo}(\mathrm{VI})$-monohydroxamic acid systems [30], indicated very strong interaction between the studied ligands and $\mathrm{Mo}(\mathrm{VI})$, but only under acidic conditions. No difference between the curves for the ligands or those registered in the $\mathrm{Mo}(\mathrm{VI})$-containing samples was observed above $\mathrm{pH}$ ca. 7.5. To illustrate this, Figure 2 shows the titration curves registered for AlaAlaNHOH alone and for the $\mathrm{Mo}(\mathrm{VI})-\mathrm{AlaAlaNHOH}$ system at various metal ion to ligand ratios.

All the titration curves can be fitted well (see fitting parameters in Table 3) for all the studied systems with the model involving the proton complexes of the ligands, hydroxido species of molybdenum(VI) (see the Experimental section), as well as the metal complexes $\left[\mathrm{MoO}_{2}(\mathrm{HL})_{2}\right]^{2+}$ and $\left[\mathrm{MoO}_{3}(\mathrm{HL})\right]$. The calculated overall stability constants of the species formed in equilibrium (1) are presented in Table 3. As an example, the inset in Figure 2 shows the concentration distribution curves of complexes formed in the $\mathrm{Mo}(\mathrm{VI})-\mathrm{AlaAlaNHOH}$ system based on $\mathrm{pH}$-metric results (similar curves were obtained for the $\mathrm{Mo}(\mathrm{VI})-\mathrm{AlaAlaN}(\mathrm{Me}) \mathrm{OH}$ system).

$$
\mathrm{MoO}_{4}{ }^{2-}+\mathrm{xL}^{-}+3 \mathrm{xH}^{+} \rightleftharpoons\left[\mathrm{MoO}_{4-\mathrm{x}}(\mathrm{HL})_{\mathrm{x}}\right]^{(\mathrm{x}-1)+}+\mathrm{xH}_{2} \mathrm{O}
$$


where $\mathrm{x}=1$ or 2 .

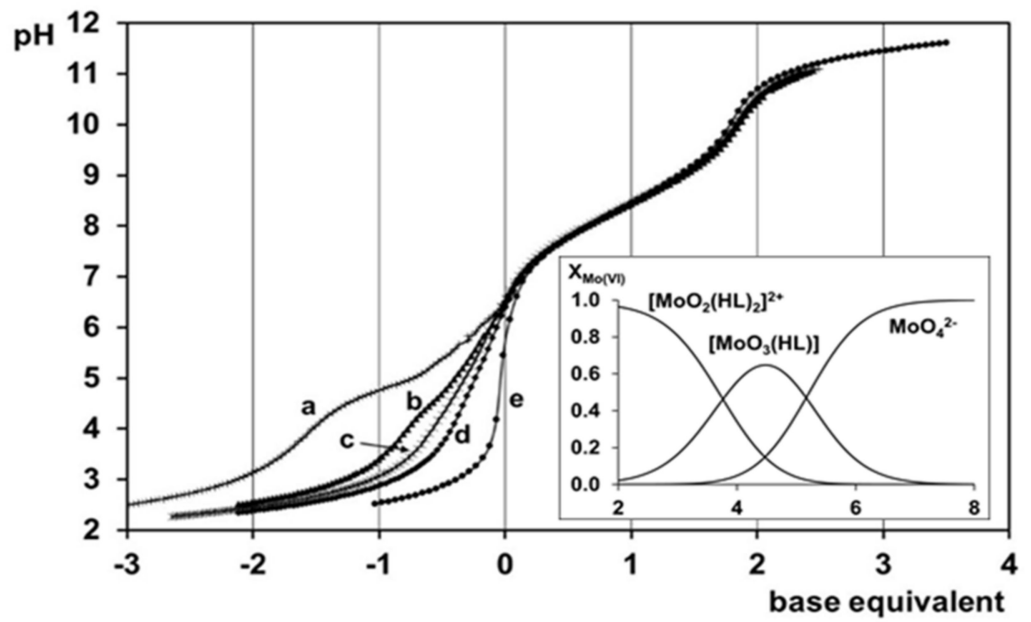

Figure 2. Titration curves of the Mo(VI)-AlaAlaNHOH system at (a) 1:1, (b) 1:2, (c) 1:3 and (d) 1:4 metal ion to ligand ratio with the titration curve of the $(\mathbf{e}) \mathrm{H}^{+}-\mathrm{AlaAlaNHOH}$ system $\left(\mathrm{c}_{\mathrm{L}}=6.00 \mathrm{mM}\right)$ and in inset the calculated concentration distribution curves for the Mo(VI)-AlaAlaNHOH system at 1:4 metal ion to ligand ratio $\left(c_{\mathrm{L}}=1.82 \mathrm{mM}\right.$; negative base equivalents refer to an excess of acid in the samples).

Table 3. Overall stability constants $(\log \beta)$ for the $\mathrm{Mo}(\mathrm{VI})$ complexes formed with the peptide hydroxamic acids at $25.0^{\circ} \mathrm{C}, \mathrm{I}=0.20 \mathrm{M}(\mathrm{KCl})^{*}$.

\begin{tabular}{ccccc}
\hline Species & AlaAlaNHOH & AlaAlaN(Me)OH & AlaGlyGlyNHOH & AlaGlyGlyN(Me)OH \\
\hline$\left[\mathrm{MoO}_{2}(\mathrm{HL})_{2}\right]^{2+}$ & $46.5(1)$ & $47.78(7)$ & $48.57(9)$ & $46.44(2)$ \\
{$\left[\mathrm{MoO}_{3}(\mathrm{HL})\right]$} & $23.89(7)$ & $24.52(5)$ & $24.37(7)$ & $23.92(2)$ \\
Fitting parameter $(\mathrm{mL})^{a}$ & 0.00317 & 0.00596 & 0.00662 & 0.00226 \\
Number of fitted data & 422 & 461 & 195 & 271 \\
\hline
\end{tabular}

${ }^{*} 3 \sigma$ standard deviations are in parentheses; ${ }^{a}$ Fitting parameter is the average difference between the calculated and experimental titration curves expressed in the volume of the titrant.

Table 3 shows no significant differences between the stability constants determined in the four systems for the two types of complexes, $\left[\mathrm{MoO}_{2}(\mathrm{HL})_{2}\right]^{2+}$ or $\left[\mathrm{MoO}_{3}(\mathrm{HL})\right]$, respectively. However, our previous results on the few $\mathrm{Mo}(\mathrm{VI})$-monohydroxamic acid systems revealed that there were some processes that were not accompanied by $\mathrm{pH}$-effect at all [30]. Consequently, pH-potentiometry alone could not detect all the solution equilibrium processes. Fortunately, additional information could be obtained using UV-Visible spectrophotometry, ${ }^{1} \mathrm{H}-\mathrm{NMR}$, and ${ }^{17} \mathrm{O}-\mathrm{NMR}$ methods. Using these methods, the following results were obtained.

A high intensity C.T. band at $\lambda_{\max }$ ca. $290 \mathrm{~nm}$ could be detected in all the studied systems as low as $\mathrm{pH} 2$, which started to decrease above $\mathrm{pH} 5$. This band is known to refer to a molybdenum-dioxidobis-hydroxamato species [30], so this finding, together with those based on ${ }^{1} \mathrm{H}-\mathrm{NMR}$ measurements, clearly supports the predominance of hydroxamate coordinated species with all the four di- and tripeptide hydroxamic acids having the amino-moiety in non-coordinated, protonated form. Beside this very important similarity in the behaviour of the four ligands toward $\mathrm{Mo}(\mathrm{VI})$, the ${ }^{1} \mathrm{H}-\mathrm{NMR}$ and especially ${ }^{17} \mathrm{O}-\mathrm{NMR}$ spectra also indicated significant differences between the interactions with the primary and secondary derivatives. This is well demonstrated by the comparison of Figure $3 a, b$ where ${ }^{1} \mathrm{H}-\mathrm{NMR}$ spectra are presented, and Figure $4 \mathrm{a}, \mathrm{b}$ where ${ }^{17} \mathrm{O}-\mathrm{NMR}$ spectra recorded at various $\mathrm{pH}$ for the $\mathrm{Mo}(\mathrm{VI})-\mathrm{AlaAlaN}(\mathrm{Me}) \mathrm{OH}$ and $\mathrm{Mo}(\mathrm{VI})-\mathrm{AlaAlaNHOH}$ systems, respectively. (Similar experimental results were obtained for the corresponding tripeptide-based counterparts; those are not shown). 


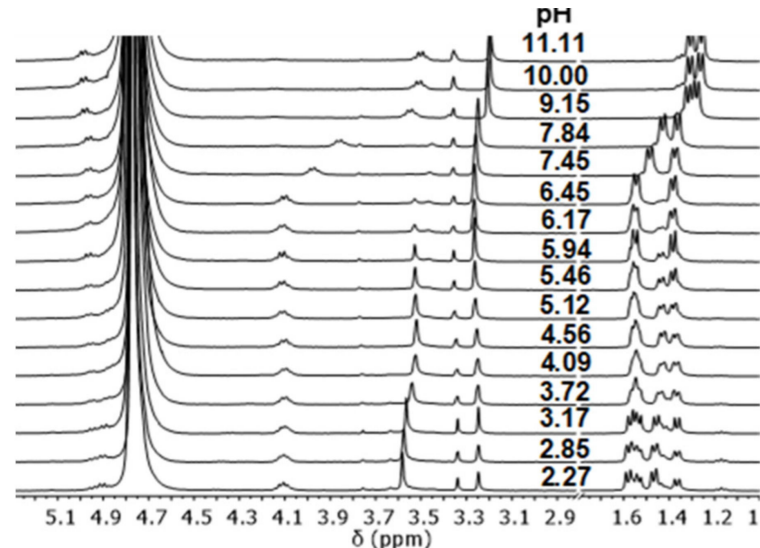

(a)

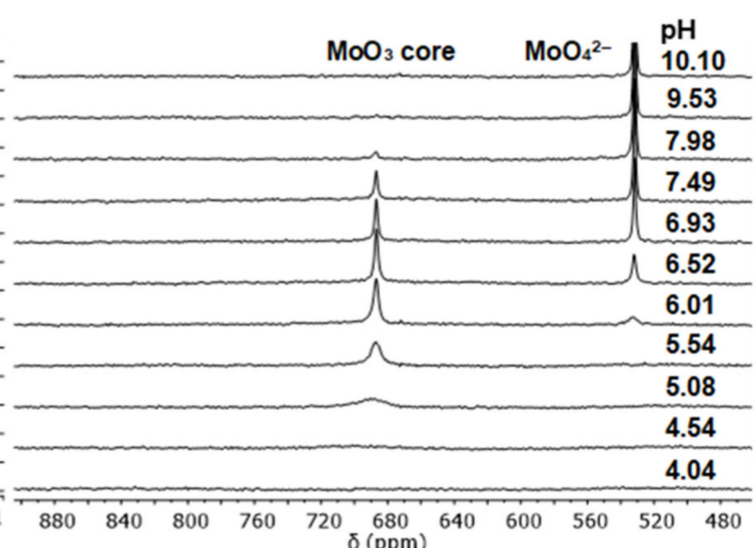

(b)

Figure 3. $\mathrm{pH}$ dependence of $(\mathbf{a}){ }^{1} \mathrm{H}-\mathrm{NMR}\left(\mathrm{c}_{\mathrm{L}}=0.015 \mathrm{M}\right)$ and $(\mathbf{b}){ }^{17} \mathrm{O}-\mathrm{NMR}\left(\mathrm{c}_{\mathrm{L}}=0.15 \mathrm{M}\right)$ spectra of the $\mathrm{Mo}(\mathrm{VI})-\mathrm{AlaAlaN}(\mathrm{Me}) \mathrm{OH}$ system at 1:3 metal ion to ligand ratio. $\left({ }^{1} \mathrm{H}-\mathrm{NMR}\right.$ signal at $3.34 \mathrm{ppm}$ refers to a few percent methanol impurity in the ligand).

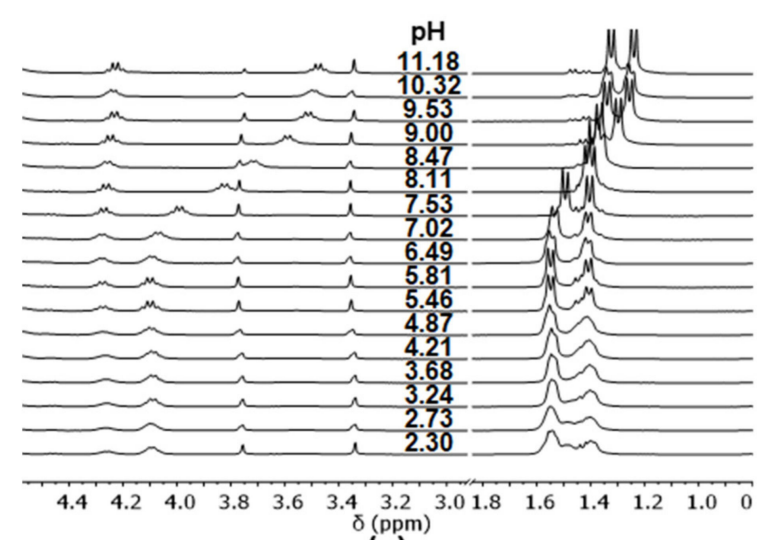

(a)

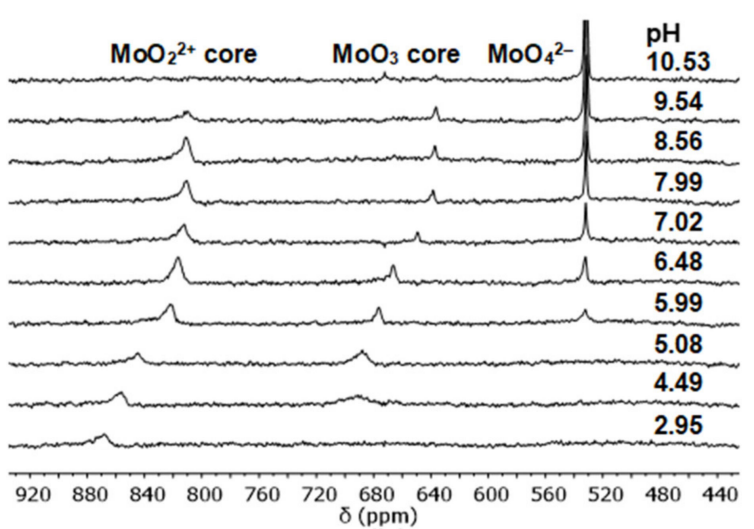

(b)

Figure 4. $\mathrm{pH}$ dependence of $(\mathbf{a}){ }^{1} \mathrm{H}-\mathrm{NMR}\left(\mathrm{c}_{\mathrm{L}}=0.015 \mathrm{M}\right)$ and $(\mathbf{b}){ }^{17} \mathrm{O}-\mathrm{NMR}\left(\mathrm{c}_{\mathrm{L}}=0.15 \mathrm{M}\right)$ spectra of the $\mathrm{Mo}(\mathrm{VI})-\mathrm{AlaAlaNHOH}$ system at 1:3 metal ion to ligand ratio. $\left({ }^{1} \mathrm{H}-\mathrm{NMR}\right.$ signal at $3.34 \mathrm{ppm}$ refers to few percent methanol impurity in the ligand).

As Figure 3a shows, complexation processes between $\mathrm{Mo}(\mathrm{VI})$ and the secondary derivative are slow enough on the NMR time scale to obtain individual signals for the non-dissociable protons locating close to the coordinating sites in the complexes compared to those for the free ligand. The fractions calculated from the relative intensities of these signals at $\mathrm{pH} 2$ (ratio of the complexed and non-complexed ligand is 2:1) are in perfect agreement with the assumption that at this $\mathrm{pH}\left[\mathrm{MoO}_{2}(\mathrm{HL})_{2}\right]^{2+}$ exists exclusively in measurable concentration, while one third of the ligand remains in non-complexed form. Some broadening of the signals belonging to the complex is observable in the spectra above $\mathrm{pH} 4$ and, parallel, small but measurable decrease in their chemical shift, either. This is the $\mathrm{pH}$, where $\left[\mathrm{MoO}_{3}(\mathrm{HL})\right]$ is present in measurable concentration by the $\mathrm{pH}$-metrically determined concentration distribution curves (see inset in Figure 2) and where the well-defined characteristic signal of the $\mathrm{MoO}_{3}$-core at $680 \mathrm{ppm}$ in the ${ }^{17} \mathrm{O}-\mathrm{NMR}$ spectrum can already be detected in Figure 3. Various exchange processes might cause the disappearance of the characteristic signal of the $\mathrm{MoO}_{2}{ }^{2+}$ core [30]. The intensity of the ${ }^{1} \mathrm{H}$ and ${ }^{17} \mathrm{O}$ signals belonging to the $\mathrm{MoO}_{3}$-containing species starts decreasing at $\mathrm{pH}$ ca. 6 and 7 , respectively, and they disappear by $\mathrm{pH}$ ca. $7.5-8$. Above this $\mathrm{pH}$, only the existence of $\mathrm{MoO}_{4}{ }^{2-}$ ions and the free secondary ligand are supported by all the used methods. Consequently, these secondary peptide-based hydroxamic acids interact with $\mathrm{Mo}(\mathrm{VI})$ in the acidic and neutral $\mathrm{pH}$-range, but they are not in the coordination sphere above neutral $\mathrm{pH}$, where only $\mathrm{MoO}_{4}{ }^{2-}$ and the free ligand exist. 
With primary derivatives, the situation is different. Although pH-potentiometry showed similar complexation behaviour with all the four studied ligands, ${ }^{1} \mathrm{H}$ and ${ }^{17} \mathrm{O}-\mathrm{NMR}$ results indicate significant differences ( $c f$. Figures 3 and 4). Very broad ${ }^{1} \mathrm{H}-\mathrm{NMR}$ signals can be seen in Figure 4a for the $\mathrm{Mo}(\mathrm{VI})-\mathrm{AlaAlaNHOH}$ system in the acidic region and sharpening of them at higher $\mathrm{pH}$. Similar observation was made in the $\mathrm{Mo}(\mathrm{VI})$-acetohydroxamic acid system, where, as a function of $\mathrm{pH}$, various inter- and intramolecular exchange processes were suggested-faster ones in the acidic region, and formation of more inert species at higher $\mathrm{pH}$ [30].

${ }^{17} \mathrm{O}-\mathrm{NMR}$ spectra of the $\mathrm{Mo}(\mathrm{VI})-\mathrm{AlaAlaNHOH}$ system were recorded between $\mathrm{pH}$ ca. $3.0-10.5$ at a metal ion to ligand ratio 1:3. The spectra in Figure $4 \mathrm{~b}$ provide the following information.

1. Although the characteristic signal of $\mathrm{MoO}_{4}{ }^{2-}$ appears at $\mathrm{pH}$ ca. 6 with this primary derivative (the same is seen in Figure $3 \mathrm{~b}$ with the secondary counterpart), to some extent, the primary ligand remains in coordinative interaction with the $\mathrm{MoO}_{2}{ }^{2+}$-core up to $\mathrm{pH}$ ca. 10. Moreover, the $\mathrm{pH}$-dependence of the chemical shift of the quite broad signals of the complexes with $\mathrm{MoO}_{2}{ }^{2+}$-core shows two inflexion points (two deprotonation processes). These experimental results support the formation of three different species with this core as a function of $\mathrm{pH}$.

2. The very broad NMR signals of $\mathrm{MoO}_{3}$ oxygens are clearly observable at ca. $688 \mathrm{ppm}$ at $\mathrm{pH} 4.49$, and their chemical shifts show one inflexion point as a function of $\mathrm{pH}$ (indicating one deprotonation step and two types of species with $\mathrm{MoO}_{3}$ core). Furthermore, its intensity starts decreasing above $\mathrm{pH} 7$ and almost disappears by $\mathrm{pH} 10.5$.

Fitting the chemical shifts vs. $\mathrm{pH}$ curves by the computer program PSEQUAD provided the following dissociation constants $(\mathrm{pK}): \mathrm{p} K_{1}=4.1(4), \mathrm{p} K_{2}=5.7(1)$ for the $\mathrm{MoO}_{2}{ }^{2+}$-containing species and $\mathrm{pK}=6.52(3)$ for the $\mathrm{MoO}_{3}$-containing one. The corresponding values with the previously studied primary acetohydroxamic acid were $\mathrm{p} K_{1}=4.45, \mathrm{p} K_{2}=6.74$, and $\mathrm{pK}=7.73$, respectively [30]. There is no doubt that similar processes can be suggested with the primary peptide hydroxamic acids as were found with acetohydroxamic acid [30], in which two factors (strong hydrogen bonding character of a hydroxamate- $\mathrm{NH}$ and possibility of deprotonation of it resulting in the formation of a hydroximate chelate with very high stability) play a crucial role. The suggested two processes are shown in Equations (2) and (3) with $\mathrm{MoO}_{2}{ }^{2+}$ core and in Equation (4) with $\mathrm{MoO}_{3}$.

$$
\begin{aligned}
{\left[\mathrm{MoO}_{2}(\mathrm{HL})_{2}\right]^{2+}+2 \mathrm{H}_{2} \mathrm{O} } & \rightleftharpoons\left[\mathrm{MoO}_{2}(\mathrm{HL})(\mathrm{OH})_{2}\right]+\mathrm{H}_{2} \mathrm{~L}^{+}+\mathrm{H}^{+} \\
{\left[\mathrm{MoO}_{2}(\mathrm{HL})(\mathrm{OH})_{2}\right] } & \rightleftharpoons\left[\mathrm{MoO}_{2}\left(\mathrm{HLH}_{-1}\right)(\mathrm{OH})_{2}\right]^{-}+\mathrm{H}^{+} \\
{\left[\mathrm{MoO}_{3}(\mathrm{HL})\left(\mathrm{H}_{2} \mathrm{O}\right)\right] } & \rightleftharpoons\left[\mathrm{MoO}_{3}\left(\mathrm{HLH}_{-1}\right)\left(\mathrm{H}_{2} \mathrm{O}\right)\right]^{-}+\mathrm{H}^{+}
\end{aligned}
$$

where HL refers to the ligand coordinated via the hydroxamate chelate and the amino moiety is still protonated. $\mathrm{HLH}_{-1}{ }^{-}$symbolizes doubly deprotonated hydroximate function, with protonated amino end.

For the investigated $\mathrm{Mo}(\mathrm{VI})$-primary peptide hydroxamic acid systems, the various most likely equilibrium processes are summarized in Scheme 3. Remarkable intramolecular exchange processes between the different species shown above (including water) result in significant broadening of the signals, as was detailed in our previous paper [30]. 


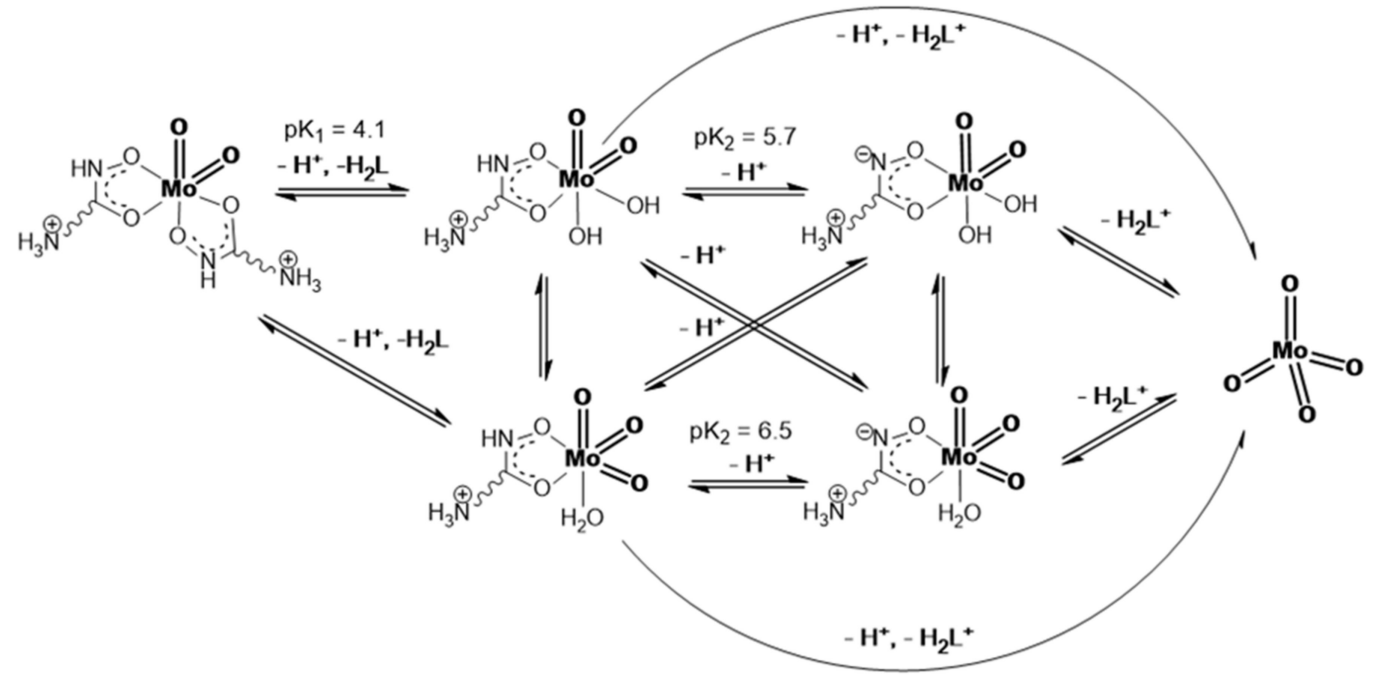

Scheme 3. The most likely equilibrium processes as a function of $\mathrm{pH}$ in $\mathrm{Mo}(\mathrm{VI})$ - primary peptide hydroxamic acid systems.

\subsection{Complexation of AlaAlaNHOH or AlaAlaN(Me)OH with Two Half-Sandwich Type} Cations- $\left[\left(\eta^{6}-p \text {-cym }\right) \mathrm{Ru}\left(\mathrm{H}_{2} \mathrm{O}\right)_{3}\right]^{2+}$ or $\left[\left(\eta^{5}-\mathrm{C} p^{*}\right) \mathrm{Rh}\left(\mathrm{H}_{2} \mathrm{O}\right)_{3}\right]^{2+}$

The speciation profiles of the complexes formed in these systems were determined via a combined use of $\mathrm{pH}$-potentiometry, ${ }^{1} \mathrm{H}-\mathrm{NMR}$, and ESI-MS. Fortunately the complex formation processes were fast enough in all of the systems to apply conventional $\mathrm{pH}$-potentiometry; for details see the Materials and Methods section. Because the titration curves registered for the two systems containing the primary derivative, AlaAlaNHOH, were similar to each other. As a representative example, the curves registered for the $\left[\left(\eta^{5}-\mathrm{Cp}^{*}\right) \mathrm{Rh}\left(\mathrm{H}_{2} \mathrm{O}\right)_{3}\right]^{2+}$-containing samples and the free ligand within the $\mathrm{pH}$-range $2-11$, together with the concentration distribution curves in inset, are depicted in Figure 5.

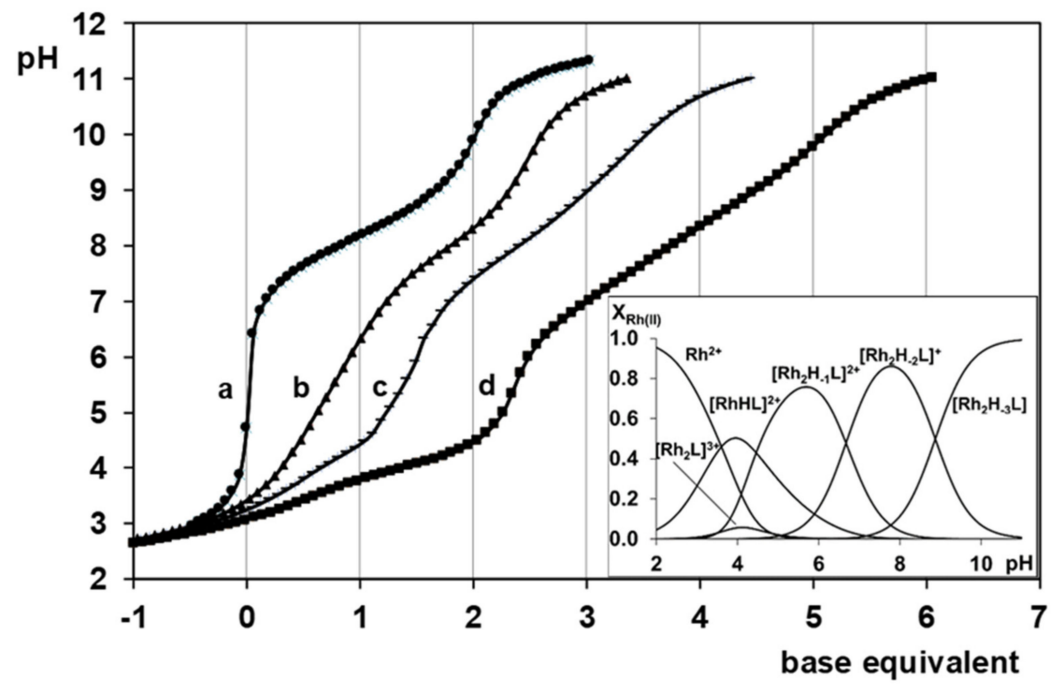

Figure 5. Titration curves of (a) the $\mathrm{H}^{+}-\mathrm{AlaAlaNHOH}$ system and the $\left[\left(\eta^{5}-\mathrm{Cp}^{*}\right) \mathrm{Rh}\left(\mathrm{H}_{2} \mathrm{O}\right)_{3}\right]^{2+}$ AlaAlaNHOH systems at (b) 1:2, (c) 1:1 and (d) 2:1 ratios $\left(\mathrm{C}_{\mathrm{L}}=1.62 \mathrm{mM}\right)$ with the related concentration distribution curves in inset calculated at 1:1 metal ion to ligand ratio $\left(c_{\mathrm{L}}=2.00 \mathrm{mM}\right.$; negative base

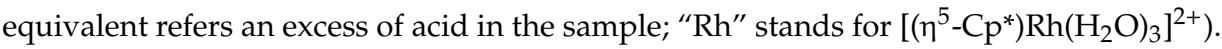

The best fit of the titration curves was obtained with the model and stability constants collected in Table 4 . 
Table 4. Overall stability constants $(\log \beta)$ for the $\left[\left(\eta^{6}-p \text {-cym }\right) \mathrm{Ru}\left(\mathrm{H}_{2} \mathrm{O}\right)_{3}\right]^{2+}$ and $\left[\left(\eta^{5}-\mathrm{Cp}{ }^{*}\right) \mathrm{Rh}\left(\mathrm{H}_{2} \mathrm{O}\right)_{3}\right]^{2+}$ complexes formed with AlaAlaNHOH and AlaAlaN(Me)OH at $25.0{ }^{\circ} \mathrm{C}, \mathrm{I}=0.20 \mathrm{M}\left(\mathrm{KNO}_{3}\right)^{*}$.

\begin{tabular}{ccccc}
\hline \multirow{2}{*}{ Species } & \multicolumn{2}{c}{ AlaAlaNHOH } & \multicolumn{2}{c}{ AlaAlaN(Me)OH } \\
\cline { 2 - 5 } & {$\left[\left(\eta^{6}-p \text {-cym)Ru }\right]^{2+}\right.$} & {$\left[\left(\eta^{5}-\mathbf{C p}^{*}\right) \mathbf{R h}\right]^{2+}$} & {$\left[\left(\eta^{6}-p \text {-cym }\right) \mathbf{R u}\right]^{2+}$} & {$\left[\left(\eta^{5}-\mathbf{C p}^{*}\right) \mathbf{R h}\right]^{2+}$} \\
\hline$[\mathrm{MHL}]^{2+}$ & $16.09(2)$ & $15.54(1)$ & $17.53(2)$ & $15.89(1)$ \\
{$[\mathrm{ML}]^{+}$} & - & - & $11.61(3)$ & $9.48(3)$ \\
{$\left[\mathrm{MH}_{-1} \mathrm{~L}\right]$} & - & - & $2.50(5)$ & $2.62(2)$ \\
{$\left[\mathrm{M}_{2} \mathrm{~L}\right]^{3+}$} & $14.95(10)$ & $13.57(8)$ & - & $14.16(2)$ \\
{$\left[\mathrm{M}_{2} \mathrm{H}_{-1} \mathrm{~L}\right]^{2+}$} & $11.16(5)$ & $10.07(1)$ & - & - \\
{$\left[\mathrm{M}_{2} \mathrm{H}_{-2} \mathrm{~L}\right]^{+}$} & $4.63(6)$ & $3.40(3)$ & - & - \\
{$\left[\mathrm{M}_{2} \mathrm{H}_{-3} \mathrm{~L}\right]$} & $-4.79(9)$ & $-5.47(4)$ & - & 0.00575 \\
Fitting parameter $(\mathrm{mL})^{\mathrm{a}}$ & 0.00683 & 0.00417 & 0.00707 & 244 \\
Number of fitted data & 302 & 183 & 201 & 6.41 \\
pK $K_{\mathrm{MHL}}$ & - & - & 5.92 & 6.86 \\
pK $K_{\mathrm{ML}}$ & - & - & 9.11 & \\
\hline
\end{tabular}

${ }^{*} 3 \sigma$ standard deviations are in parentheses; ${ }^{a}$ Fitting parameter is the average difference between the calculated and experimental titration curves expressed in the volume of the titrant.

As it is clearly seen in Table 4, identical equilibrium models were determined for the $\left[\left(\eta^{6}-p-c y m\right) \mathrm{Ru}\left(\mathrm{H}_{2} \mathrm{O}\right)_{3}\right]^{2+}-\mathrm{AlaAlaNHOH}$ and $\left[\left(\eta^{5}-\mathrm{Cp}^{*}\right) \mathrm{Rh}\left(\mathrm{H}_{2} \mathrm{O}\right)_{3}\right]^{2+}-\mathrm{AlaAlaNHOH}$ systems. The only difference is that the stability constants are slightly higher for the complexes with the Ru-containing cation compared to Rh similarly as it was previously found with monohydroxamic acids and with aminohydroxamic acids [13,31]. Surprisingly, as Table 4 shows, apart from $[\mathrm{MHL}]^{2+}$, only dinuclear complexes are formed in these systems, which predominate even at 1:1 metal ion to ligand ratio (see inset in Figure 5) and at ligand excess. The suggested coordination mode in the only mononuclear protonated complex is shown as structure IV in Scheme 4. (As an example, the binding modes are shown for the complexes formed with $\left[\left(\eta^{6}-p \text {-cym) } \mathrm{Ru}\left(\mathrm{H}_{2} \mathrm{O}\right)_{3}\right]^{2+}\right.$ but those are the same in the corresponding $\left[\left(\eta^{5}-\mathrm{Cp}^{*}\right) \mathrm{Rh}\left(\mathrm{H}_{2} \mathrm{O}\right)_{3}\right]^{2+}$ containing complexes.)

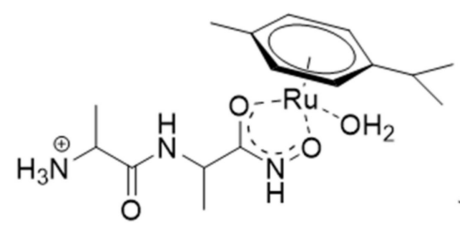

IV

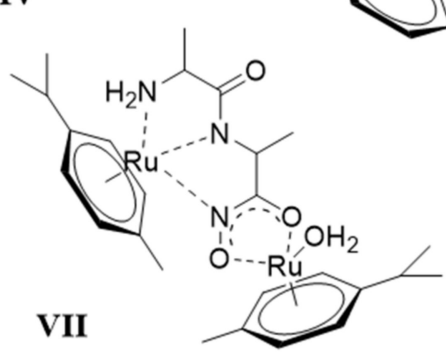

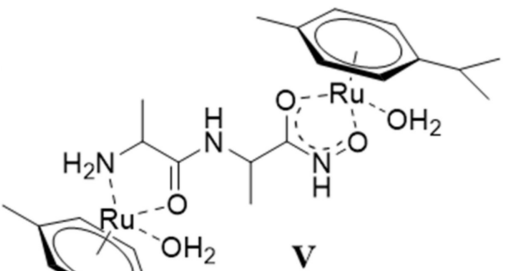

$\mathbf{V}$
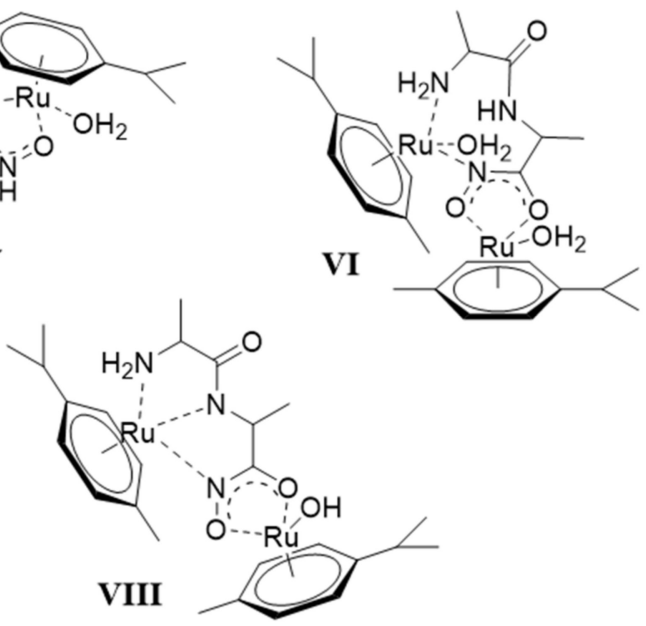

Scheme 4. Suggested structures for the complexes formed in $\left[\left(\eta^{6}-p \text {-cym }\right) \mathrm{Ru}\left(\mathrm{H}_{2} \mathrm{O}\right)_{3}\right]^{2+}-\mathrm{AlaAlaNHOH}$ systems.

In IV, the hydroxamate chelate (having rather high conditional stability even under strongly acidic conditions with these metal ions [13]), together with a water molecule saturate the three coordination sites of a half-sandwich cation, while the amino group is protonated. The hydroxamate and, after deprotonation of the hydroxamate- $\mathrm{NH}$, the hydroximate chelate is not displaced by other coordinating donors of this dipeptide-based primary hydroxamic acid remaining coordinated in the whole studied $\mathrm{pH}$-range. That is the reason why the amino- $\mathrm{N}$, the peptide moiety, and the hydroximate- $\mathrm{N}$ can only coordinate to another metal cation, forming dinuclear complexes in this way. The dominance 
of the dinuclear species might cause the high complexity of the ${ }^{1} \mathrm{H}-\mathrm{NMR}$ spectra for the signals of the methyl groups of the $\mathrm{Cp}^{*}$ ligand and especially that of the $p$-cymene aromatic protons above $\mathrm{pH}$ ca. 4. To illustrate this, $\mathrm{pH}$-dependent chemical shifts of the $p$-cymene aromatic protons are shown in Figure S2. Additional support for the dominant formation of dinuclear complexes with AlaAlaNHOH in these systems was obtained by ESI-MS with the direct identification of $\left[\mathrm{M}_{2} \mathrm{H}_{-2} \mathrm{~L}\right]^{+}$at and above $\mathrm{pH}=8.01$ (see Figure S3 for the measured and calculated spectra of this species).

The suggested binding modes in the dinuclear complexes $\left[\mathrm{M}_{2} \mathrm{~L}\right]^{3+},\left[\mathrm{M}_{2} \mathrm{H}_{-1} \mathrm{~L}\right]^{2+},\left[\mathrm{M}_{2} \mathrm{H}_{-2} \mathrm{~L}\right]^{+}$, and $\left[\mathrm{M}_{2} \mathrm{H}_{-3} \mathrm{~L}\right]$ are shown as structures V, VI, VII and VIII, respectively, in Scheme 4.

Although the complexation processes with the secondary AlaAlaN(Me)OH were somewhat slower compared to those with the primary AlaAlaNHOH, they were still fast enough to perform direct $\mathrm{pH}$-metric titrations. Because for AlaAlaN(Me)OH, the substitution of the hydrogen at the hydroxamic-nitrogen by a methyl moiety hinders the formation of either the hydroximate chelate with very high stability or the $\left(\mathrm{NH}_{2}, \mathrm{~N}_{\text {amide }}, \mathrm{N}_{\text {hydr }}\right)$ tridentate coordination mode (both playing a very important role in the interaction between AlaAlaNHOH and the two studied metal ions, as seen in structures VI, VII and VIII), the significant differences between the equilibrium models obtained with the primary and secondary dipeptide hydroxamic acids (Table 4) are understandable. Apart from the minor species, $\left[\mathrm{M}_{2} \mathrm{~L}\right]^{3+}$, with $\left[\left(\eta^{5}-\mathrm{Cp}^{*}\right) \mathrm{Rh}\left(\mathrm{H}_{2} \mathrm{O}\right)_{3}\right]^{2+}$ in an intermediate $\mathrm{pH}$-range, only mononuclear complexes are seen in Table 4 with the secondary ligand. The model was also supported by the ESI-MS results. The existence of $[\mathrm{ML}]^{+}$and $\left[\mathrm{MH}_{-1} \mathrm{~L}\right]$ were detected (the latter in its adduct with $\mathrm{K}^{+}$) in both systems, while $\left[\mathrm{M}_{2} \mathrm{~L}\right]^{3+}$ was detected only with $\left[\left(\eta^{5}-\mathrm{Cp}\right) \mathrm{Rh}\left(\mathrm{H}_{2} \mathrm{O}\right)_{3}\right]^{2+}$. The corresponding $\mathrm{m} / \mathrm{z}$ values are shown in Table S1. Despite the almost identical equilibrium models, the binding modes cannot be the same in all of the suggested complexes with AlaAlaN(Me)OH and the two half-sandwich cations because the $\mathrm{pH}$-metric titration curves indicate significant differences. This is demonstrated in Figure 6, where the titration curve of the ligand, and those registered at 1:1 metal ion to ligand ratio with the two cations are presented. In inset of Figure 6, the concentration distribution curves calculated using the $\mathrm{pH}$-metric results are also shown.

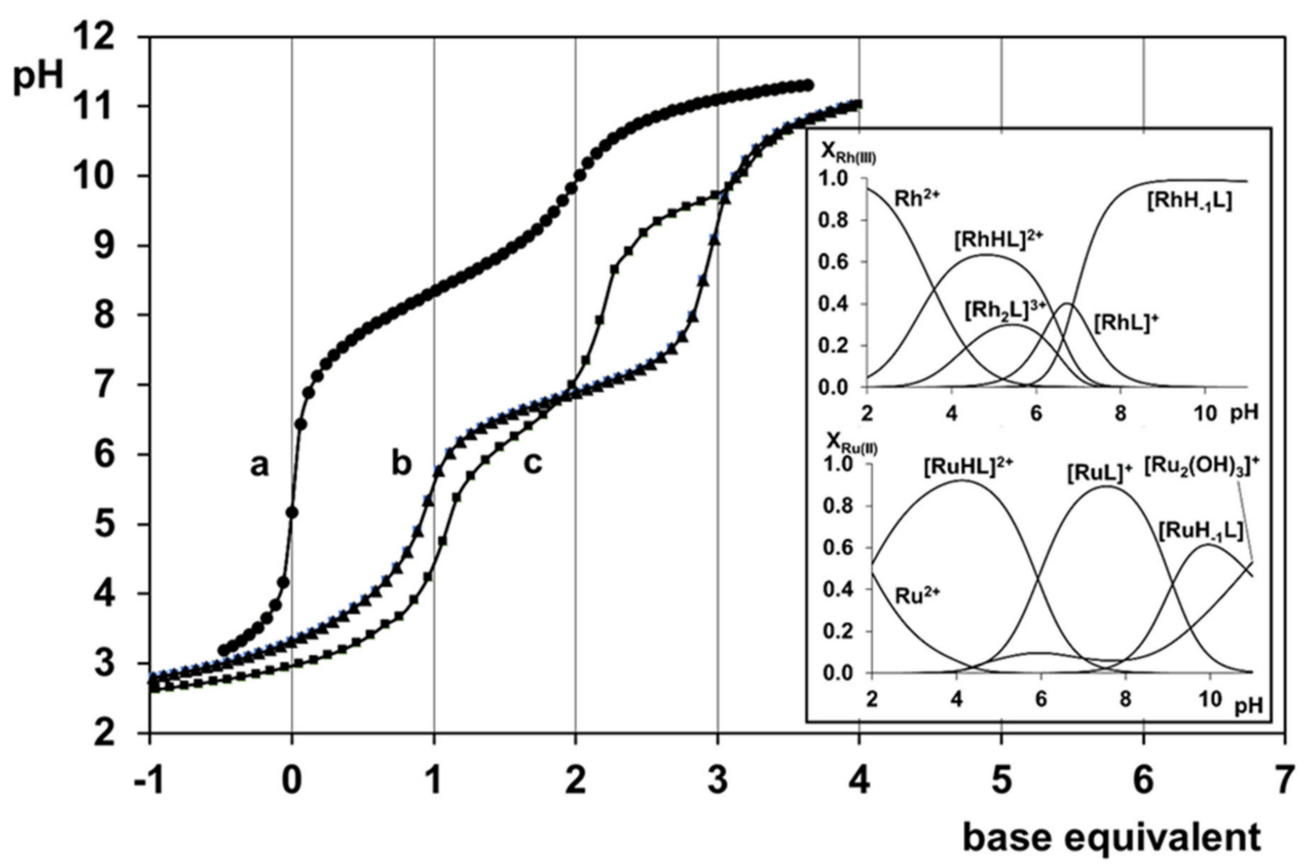

Figure 6. Representative titration curves for the (a) $\mathrm{H}^{+}-\mathrm{AlaAlaN}(\mathrm{Me}) \mathrm{OH},(\mathbf{b})\left[\left(\eta^{5}-\mathrm{Cp} \mathrm{p}^{*}\right) \mathrm{Rh}\left(\mathrm{H}_{2} \mathrm{O}\right)_{3}\right]^{2+}-$ AlaAlaN(Me)OH, and (c) $\left[\left(\eta^{6}-p-c y m\right) R u\left(\mathrm{H}_{2} \mathrm{O}\right)_{3}\right]^{2+}-\mathrm{AlaAlaN}(\mathrm{Me}) \mathrm{OH}$ systems with their related concentration distribution curves in inset at 1:1 metal ion to ligand ratio. $\left(c_{\mathrm{L}}=1.80 \mathrm{mM}\right.$; negative base equivalent refers an excess of acid in the sample; "Rh" stands for $\left[\left(\eta^{5}-\mathrm{Cp}^{*}\right) \mathrm{Rh}\left(\mathrm{H}_{2} \mathrm{O}\right)_{3}\right]^{2+} ;$; $\mathrm{Ru}$ " stands for $\left.\left[\left(\eta^{6}-p-c y m\right) R u\left(H_{2} \mathrm{O}\right)_{3}\right]^{2+}\right)$. 
As can be seen in Table 4, the stability constants obtained for the $[\mathrm{MHL}]^{2+}$ complexes are similar to the values of the corresponding ones with AlaAlaNHOH. This supports the same coordination mode (IV in Scheme 4) in $[\mathrm{MHL}]^{2+}$ in all the studied systems. With the secondary ligand, however, this species is formed in a wider $\mathrm{pH}$-range and higher extent than with the primary counterpart ( $c f$. the corresponding speciation curves in Insets in Figures 5 and 6). The complex $\left[\mathrm{M}_{2} \mathrm{~L}\right]^{3+}$, which was found only with the $\mathrm{Rh}$ (III)-containing cation, most probably has the binding mode shown in structure $\mathrm{V}$ in Scheme 4 . Above $\mathrm{pH}$ ca. $5[\mathrm{ML}]^{+}$is formed in both systems, but predominates only in the $\left[\left(\eta^{6}-p-c y m\right) \mathrm{Ru}\left(\mathrm{H}_{2} \mathrm{O}\right)_{3}\right]^{2+}-\mathrm{AlaAlaN}(\mathrm{Me}) \mathrm{OH}$ system between $\mathrm{pH}$ ca. 6-8.5, while its amount is not significant at all with $\left[\left(\eta^{5}-\mathrm{Cp}^{*}\right) \mathrm{Rh}\left(\mathrm{H}_{2} \mathrm{O}\right)_{3}\right]^{2+}$. Assuming that the terminal- $\mathrm{NH}_{3}{ }^{+}$deprotonates in the $[\mathrm{MHL}]^{2+} \rightleftharpoons[\mathrm{ML}]^{+}+\mathrm{H}^{+}$equilibrium process, the $\mathrm{pK}$ values, that can be calculated using the corresponding stability constants in Table $4(17.53-11.61=5.92$ for the complex with $\left[\left(\eta^{6}-p \text {-cym }\right) \mathrm{Ru}\left(\mathrm{H}_{2} \mathrm{O}\right)_{3}\right]^{2+}$, while $15.89-9.48=6.41$ for the complex with $\left.\left[\left(\eta^{5}-\mathrm{Cp}{ }^{*}\right) \mathrm{Rh}\left(\mathrm{H}_{2} \mathrm{O}\right)_{3}\right]^{2+}\right)$ are significantly lower than the $\mathrm{pK}$ of the free ligand (see Table 1 ). This strongly suggests the coordination of the terminal amino- $\mathrm{N}$ in the $[\mathrm{ML}]^{+}$species. However, due to sterical reasons, the simultaneous coordination of the $(\mathrm{O}, \mathrm{O})_{\text {hydr }}$ chelate and that of the amino-N are not possible at the three available sites of the same metal ion, and the stoichiometry of this species should be $\left[\mathrm{M}_{\mathrm{x}} \mathrm{L}_{\mathrm{x}}\right]^{\mathrm{x}+}$. The suggested structure for $\left[\mathrm{M}_{2} \mathrm{~L}_{2}\right]^{2+}$ is shown as structure IX in Scheme 5. Unfortunately, the methods applied could not provide direct information for the number of $x$, additional investigations are necessary to address this problem.
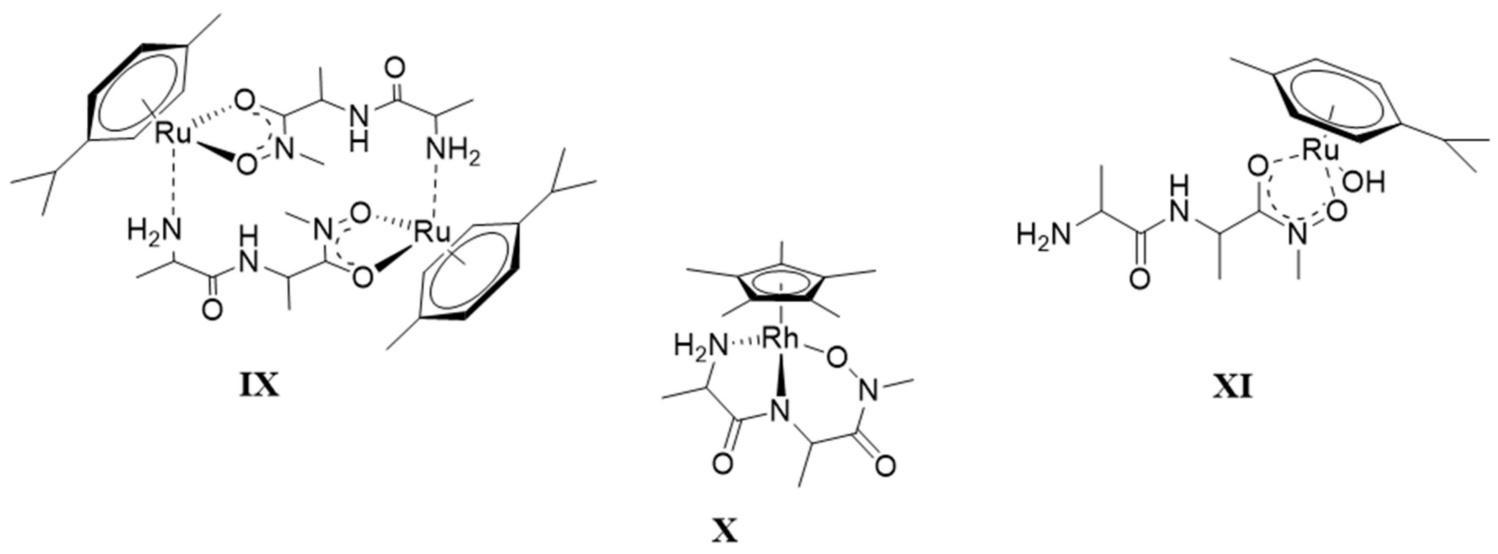

XI

Scheme 5. Suggested binding modes for the complexes formed in half-sandwich metal ionAlaAlaN(Me)OH systems.

On the contrary, rather large differences can be expected between the binding modes in $\left[\mathrm{MH}_{-1} \mathrm{~L}\right]$ formed with the two cations. As the comparison of curves $b$ and $c$ in Figure 6 reveals, the dissociation processes $[\mathrm{MHL}]^{2+} \rightleftharpoons\left[\mathrm{ML}^{+}+\mathrm{H}^{+}\right.$and $[\mathrm{ML}]^{+} \rightleftharpoons\left[\mathrm{MH}_{-1} \mathrm{~L}\right]+\mathrm{H}^{+}$overlap with each other considerably in the $\left[\left(\eta^{5}-\mathrm{Cp}^{*}\right) \mathrm{Rh}\left(\mathrm{H}_{2} \mathrm{O}\right)_{3}\right]^{2+}$-containing system (the corresponding $\mathrm{pK}$ values are 6.41 and 6.86 in Table 4), while those are completely separated from each other in the other system (the stepwise $\mathrm{pK}$ values are 5.92 and 9.11). The reason of this large difference originates from the rather different hydrolytic behaviour of the two half-sandwich cations, being the hydrolysis of the ruthenium-containing cation more pronounced [32]. As a consequence, $\left[\mathrm{MH}_{-1} \mathrm{~L}\right]$ can be formed with $\left(\mathrm{NH}_{2}, \mathrm{~N}_{\text {amide }}, \mathrm{O}_{\text {hydr }}\right)$ tridentate coordination mode in the $\left[\left(\eta^{5}-\mathrm{Cp}^{*}\right) \mathrm{Rh}\left(\mathrm{H}_{2} \mathrm{O}\right)_{3}\right]^{2+}-\mathrm{AlaAlaN}(\mathrm{Me}) \mathrm{OH}$ system only (structure $\mathrm{X}$ in Scheme 4), while the species with the same stoichiometry is a mixed hydroxido complex for the other metal ion (structure XI in Scheme 5).

\subsection{Complexation of AlaGlyGlyNHOH or AlaGlyGlyN(Me)OH with the Two Half-Sandwich Type Cations- $\left[\left(\eta^{6}-p-c y m\right) R u\left(\mathrm{H}_{2} \mathrm{O}\right)_{3}\right]^{2+}$ or $\left[\left(\eta^{5}-\mathrm{C} p^{*}\right) \mathrm{Rh}\left(\mathrm{H}_{2} \mathrm{O}\right)_{3}\right]^{2+}$}

Unfortunately, conventional $\mathrm{pH}$-metric titrations could only be carried out below $\mathrm{pH}$ ca. 6 for the two systems containing one of the studied tripeptide hydroxamic acids and the $\left[\left(\eta^{6}-p-c y m\right) R u\left(H_{2} \mathrm{O}\right)_{3}\right]^{2+}$ cation. Above this $\mathrm{pH}$, the processes became too slow to reach $\mathrm{pH}$ equilibrium within maximum $30 \mathrm{~min}$ (see Materials and Methods section). As a consequence, calculations relating to the stoichiometry and 
stability constant of the complexes formed in these systems could only be carried out below $\mathrm{pH} 6$. According to the $\mathrm{pH}$-metric titration curves, however, the behaviour of the two ligands toward this half-sandwich cation is significantly different even in this narrow $\mathrm{pH}$-range. For the primary derivative, two equivalents of base are consumed below pH 6 at 1:1 metal ion to ligand ratio, but only one with the secondary counterpart. There is no doubt that one equivalent base, in the $\mathrm{pH}$-range ca. 2.5-4.5, is consumed for the neutralization of the proton released from the hydroxamic function and the $(\mathrm{O}, \mathrm{O})_{\text {hydr }}$ chelate is formed. Direct proof for this assumption was obtained from the ${ }^{1} \mathrm{H}-\mathrm{NMR}$ spectra, in which e.g., a new singlet of the C-terminal glycine- $\mathrm{CH}_{2}$ protons (designated as " $\mathrm{D}$ " protons in the formula of AlaGlyGlyNHOH in Scheme 1) refers to the complex at $3.96 \mathrm{ppm}$, while the one for the non-complexed ligand is seen at $3.92 \mathrm{ppm}$. Indication is provided for the coordination of the amino- $\mathrm{N}$ in the $\mathrm{pH}$-range of this second base-consuming process by the signal of the " $\mathrm{B}$ " protons in the ${ }^{1} \mathrm{H}-\mathrm{NMR}$ spectra (the new signal belonging to the complex appears at $3.32 \mathrm{ppm}$ ). Most probably, due to sterical reasons this process was not observable with AlaGlyGlyN(Me)OH below $\mathrm{pH} 6$ (spectra for this latter system are not presented here). The stoichiometries and the overall stability constants of the complexes yielding the best fit of the titration curves below $\mathrm{pH} 6$ are as follows: $\left[\left(\eta^{6}-p \text {-cym }\right) \mathrm{Ru}\left(\mathrm{H}_{2} \mathrm{O}\right)_{3}\right]^{2+}$-AlaGlyGlyNHOH: $\log \beta_{[\mathrm{MHL}] 2+}=17.19(2), \log \beta_{[\mathrm{ML}]+}=13.33(3) ;\left[\left(\eta^{6}-p-\mathrm{cym}\right) \mathrm{Ru}\left(\mathrm{H}_{2} \mathrm{O}\right)_{3}\right]^{2+}-\mathrm{AlaGlyGlyN}(\mathrm{Me}) \mathrm{OH}: \log \beta_{[\mathrm{MHL}] 2+}$ $=17.14(2)$.

${ }^{1} \mathrm{H}-\mathrm{NMR}$ measurements were also performed up to $\mathrm{pH}$ ca. 11 in these two systems, but detailed evaluation of them was not made because the spectra registered one hour after the preparation of the samples, as was often the case (see Materials and Methods section), which clearly did not refer to the equilibrium state in these samples above $\mathrm{pH}$ ca. 6 . This was unambiguously supported by control measurements on a few samples where up to five days from the first registration the spectra were monitored again.

Fortunately, the processes were fast enough to perform $\mathrm{pH}$-metric titrations in the $\left[\left(\eta^{5}-\mathrm{Cp}^{*}\right) \mathrm{Rh}\left(\mathrm{H}_{2} \mathrm{O}\right)_{3}\right]^{2+}-\mathrm{AlaGlyGlyN}(\mathrm{Me}) \mathrm{OH}$ or -AlaGlyGlyNHOH systems, as demonstrated by Figure $7 \mathrm{a}, 7 \mathrm{~b}$, respectively. The stoichiometry and overall stability constants of the complexes providing the best fit of the titration curves, together with the suggested binding modes of the complexes, are listed in Table 5. Concentration distribution curves calculated for the complexes formed in the above systems at 1:1 metal ion to ligand ratio using the corresponding stability constants are shown in Figure $7 \mathrm{c}, \mathrm{d}$, respectively.

Although some noticeable differences can be seen between the titration curves registered for the systems containing the primary and secondary ligands, Table 5 shows almost the same equilibrium models for the two systems (except the species $\left[\mathrm{M}_{2} \mathrm{H}_{2} \mathrm{~L}\right]^{+}$, which was formed only with the primary derivative). A comparison of the two speciation profiles in Figure $7 \mathrm{c}$, d however, indicated significant differences, especially in the intermediate $\mathrm{pH}$-range (ca. 5-8). These differences are also supported by the ${ }^{1} \mathrm{H}-\mathrm{NMR}$ spectra registered for the systems at 1:1 and 2:1 metal ion to ligand ratios. To illustrate this, Figure 8 shows the pH-dependence of the chemical shifts of the methyl (A) and (E) protons of AlaGlyGlyN(Me)OH as well as (A) protons of AlaGlyGlyNHOH in presence of equimolar amount of $\left[\left(\eta^{5}-\mathrm{Cp}^{*}\right) \mathrm{Rh}\left(\mathrm{H}_{2} \mathrm{O}\right)_{3}\right]^{2+}$ in the $\mathrm{pH}-$-range ca. $2-11$. Figure 8 reveals that individual signals belong to each of the complexes as well as to the free ligands in these systems. Consequently, the NMR results provided clear support to the speciation model and to the determination of the most likely binding modes in the complexes. (As an example, the registered spectra as a function of $\mathrm{pH}$ for the $\left[\left(\eta^{5}-\mathrm{Cp}^{*}\right) \mathrm{Rh}\left(\mathrm{H}_{2} \mathrm{O}\right)_{3}\right]^{2+}-\mathrm{AlaGlyGlyN}(\mathrm{Me}) \mathrm{OH}$ system are shown in the Supplementary Figure S4.) 


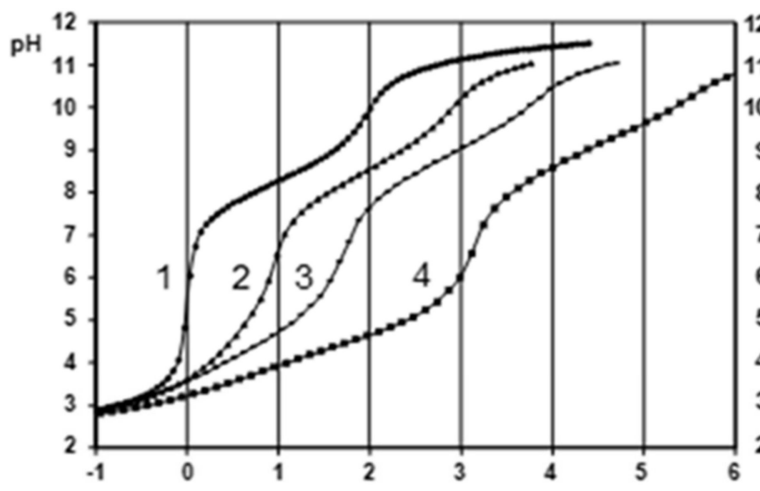

(a)

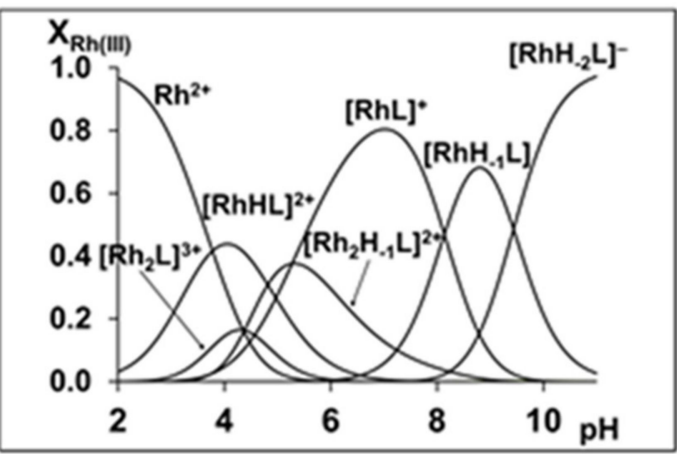

(c)

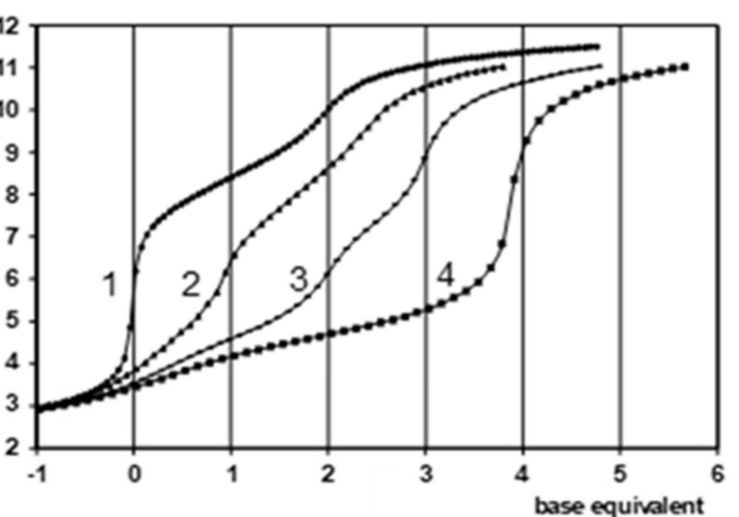

(b)

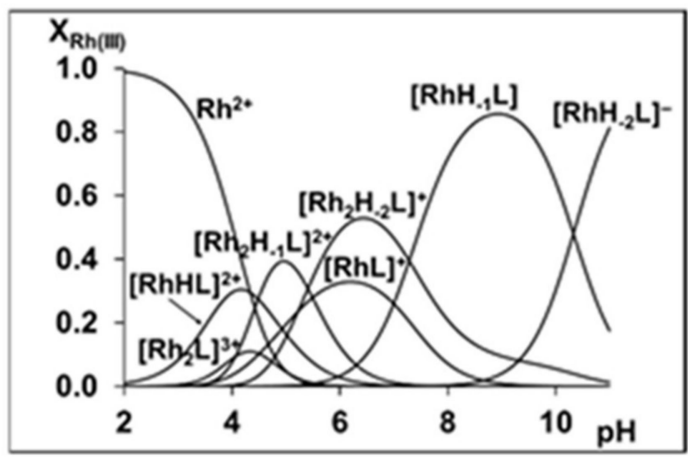

(d)

Figure 7. Titration curves with (a) AlaGlyGlyN(Me)OH and (b) AlaGlyGlyNHOH for (1) the $\mathrm{H}^{+}$-ligand and the $\left[\left(\eta^{5}-\mathrm{Cp}^{*}\right) \mathrm{Rh}\left(\mathrm{H}_{2} \mathrm{O}\right)_{3}\right]^{2+}$-ligand systems at (2) $1: 2$, (3) 1:1, and (4) 2:1 ratios $\left(\mathrm{c}_{\mathrm{L}}=1.62-1.82 \mathrm{mM}\right.$, $\left.\mathrm{I}=0.20 \mathrm{M} \mathrm{KNO}_{3}\right)$; Calculated speciation curves for $(\mathbf{c})$ the $\left[\left(\eta^{5}-\mathrm{Cp}^{*}\right) \mathrm{Rh}\left(\mathrm{H}_{2} \mathrm{O}\right)_{3}\right]^{2+}-$ AlaGlyGlyN$(\mathrm{Me}) \mathrm{OH}$ $\left(\mathrm{c}_{\mathrm{L}}=1.82 \mathrm{mM}\right)$ and $(\mathrm{d})\left[\left(\eta^{5}-\mathrm{Cp}^{*}\right) \mathrm{Rh}\left(\mathrm{H}_{2} \mathrm{O}\right)_{3}\right]^{2+}-\mathrm{AlaGlyGlyNHOH}\left(\mathrm{c}_{\mathrm{L}}=1.62 \mathrm{mM}\right)$ systems at 1:1 ratio (negative base equivalent refers an excess of acid in the sample, " $\mathrm{Rh}$ " stands for $\left.\left[\left(\eta^{5}-\mathrm{C} \mathrm{p}^{*}\right) \mathrm{Rh}\left(\mathrm{H}_{2} \mathrm{O}\right)_{3}\right]^{2+}\right)$.

Table 5. Overall stability constants $(\log \beta)$ for the $\left[\left(\eta^{5}-\mathrm{Cp}^{*}\right) \mathrm{Rh}\left(\mathrm{H}_{2} \mathrm{O}_{3}\right]^{2+}\right.$ complexes formed with tripeptide hydroxamic acids, together with their suggested binding modes at $25.0^{\circ} \mathrm{C}, \mathrm{I}=0.20 \mathrm{M}\left(\mathrm{KNO}_{3}\right)^{*}$.

\begin{tabular}{ccccc}
\hline \multirow{2}{*}{ Species } & \multicolumn{3}{c}{ AlaGlyGlyN(Me)OH } & AlaGlyGlyNHOH \\
\cline { 2 - 5 } & $\log \beta$ & Coordinated Donor Atoms & $\log \beta$ & Coordinated Donor Atoms \\
\hline$[\mathrm{MHL}]^{2+}$ & $15.53(4)$ & $(\mathrm{O}, \mathrm{O})_{\text {hydr }}$ & $15.35(4)$ & $(\mathrm{O}, \mathrm{O})_{\text {hydr }}$ \\
{$\left[\mathrm{ML}^{+}\right.$} & $10.56(7)$ & $\left(\mathrm{NH}_{2}, \mathrm{~N}_{\text {amide }}\right)$ & $10.42(6)$ & $\left(\mathrm{NH}_{2}, \mathrm{~N}_{\text {amide }}\right)$ \\
{$\left[\mathrm{MH}_{-1} \mathrm{~L}\right]$} & $2.42(6)$ & $\left(\mathrm{NH}_{2}, \mathrm{~N}_{\text {amide }}\right)$ & $3.42(4)$ & $\left(\mathrm{NH}_{2}, \mathrm{~N}_{\text {amide }}, \mathrm{N}_{\text {hydr }}\right)$ \\
{$\left[\mathrm{MH}_{-2} \mathrm{~L}\right]^{-}$} & $-7.02(7)$ & $\left(\mathrm{NH}_{2}, \mathrm{~N}_{\text {amide, }}, \mathrm{N}_{\text {amide }}\right)$ & $-6.91(3)$ & $\left(\mathrm{NH}_{2}, \mathrm{~N}_{\text {amide }}, \mathrm{N}_{\text {amide }}\right)$ \\
{$\left[\mathrm{M}_{2} \mathrm{~L}\right]^{3+}$} & $14.0(1)$ & $(\mathrm{O}, \mathrm{O})_{\text {hydr }}+\left(\mathrm{NH}_{2}, \mathrm{CO}\right)$ & $13.6(1)$ & $(\mathrm{O}, \mathrm{O})_{\text {hydr }}+\left(\mathrm{NH}_{2}, \mathrm{CO}\right)$ \\
{$\left[\mathrm{M}_{2} \mathrm{H}_{-1} \mathrm{~L}\right]^{2+}$} & $9.62(5)$ & $(\mathrm{O}, \mathrm{O})_{\text {hydr }}+\left(\mathrm{NH}_{2}, \mathrm{~N}_{\text {amide }}\right)$ & $9.53(3)$ & $(\mathrm{O}, \mathrm{O})_{\text {hydr }}+\left(\mathrm{NH}_{2}, \mathrm{~N}_{\text {amide }}\right)$ \\
{$\left[\mathrm{M}_{2} \mathrm{H}_{-2} \mathrm{~L}^{+}\right.$} & - & & $4.12(3)$ & $(\mathrm{O}, \mathrm{O})_{\text {hydr }}+\left(\mathrm{NH}_{2}, \mathrm{~N}_{\text {amide, }}, \mathrm{N}_{\text {hydr }}\right)$ \\
Fitting parameter $(\mathrm{mL})^{\mathrm{a}}$ & 0.0123 & & 0.00599 & \\
Number of fitted data & 265 & & 256 & \\
\hline
\end{tabular}

${ }^{*}$ For the $\log \beta$ values, $3 \sigma$ standard deviations are in parentheses; ${ }^{a}$ Fitting parameter is the average difference between the calculated and experimental titration curves expressed in the volume of the titrant; coordinated water molecules at the third coordination sites are omitted. 


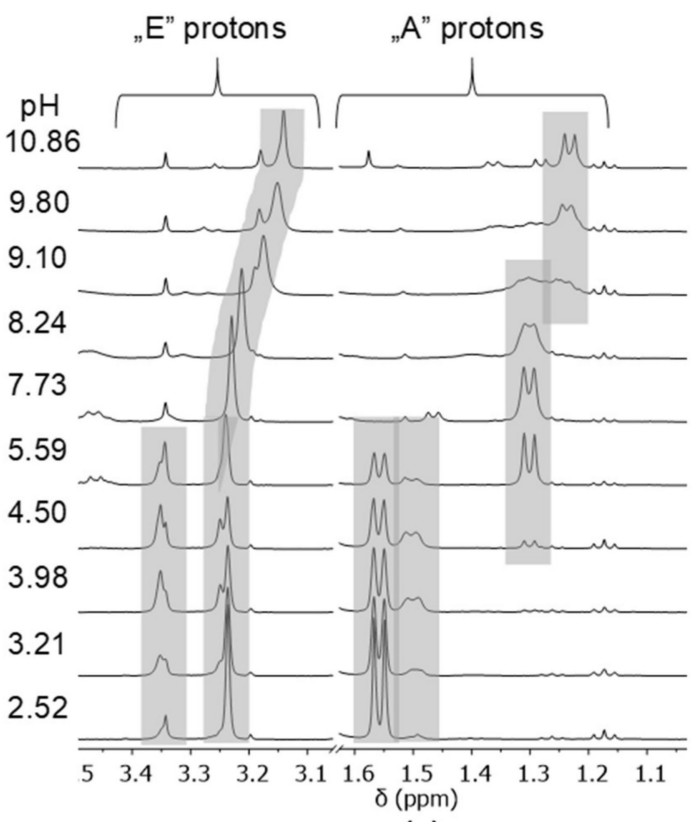

(a)

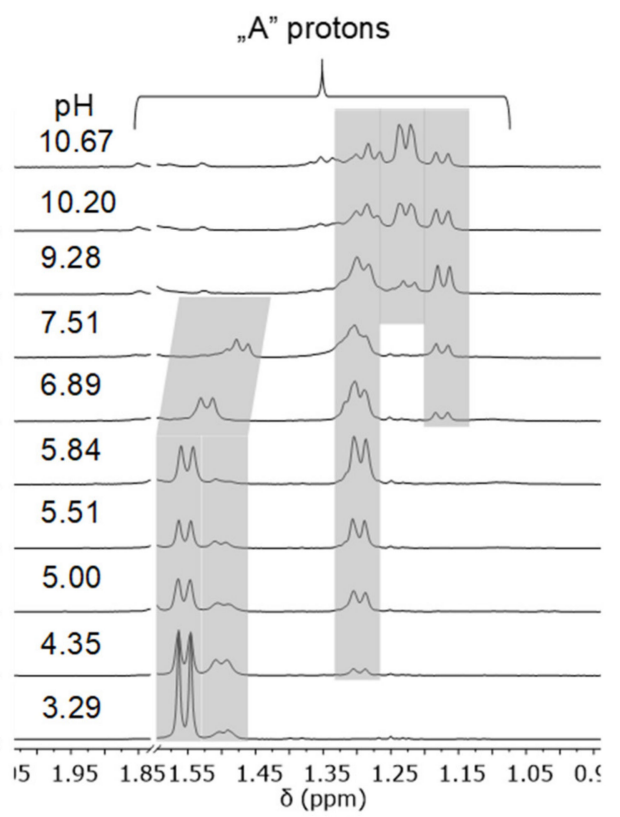

(b)

Figure 8. ${ }^{1} \mathrm{H}-\mathrm{NMR}$ signals of $\mathrm{E}$ (singlets) and A (doublets) protons of the species formed in the (a) $\left[\left(\eta^{5}-\mathrm{Cp}^{*}\right) \mathrm{Rh}\left(\mathrm{H}_{2} \mathrm{O}\right)_{3}\right]^{2+}-$ AlaGlyGlyN$(\mathrm{Me}) \mathrm{OH}$ and $(\mathbf{b})\left[\left(\eta^{5}-\mathrm{Cp}^{*}\right) \mathrm{Rh}\left(\mathrm{H}_{2} \mathrm{O}\right)_{3}\right]^{2+}-$ AlaGlyGlyNHOH systems at 1:1 metal ion to ligand ratio as a function of $\mathrm{pH}\left(\mathrm{c}_{\mathrm{L}}=5.00 \mathrm{mM} ;{ }^{1} \mathrm{H}-\mathrm{NMR}\right.$ signal at $3.34 \mathrm{ppm}$ refers to methanol impurity in the ligand).

The conclusions, which can be drawn from a comparison of the equilibrium models/stability constants in Table 5, from the concentration distribution curves shown in Figure 7c,d and from the selected ${ }^{1} \mathrm{H}-\mathrm{NMR}$ signals presented in Figure 8 are as follows: With the secondary derivative, the complexation starts above $\mathrm{pH}$ ca. 2 with the formation of $[\mathrm{MHL}]^{2+}$, in which $(\mathrm{O}, \mathrm{O})_{\text {hydr }}$ coordination mode is supported (a singlet in Figure 8 a at 3.35 ppm belongs to the N-methyl (E) protons situating in the complexed ligand, while another one at $3.22 \mathrm{ppm}$ to the protonated free ligand. The doublet at $1.55 \mathrm{ppm}$ refers to the methyl protons of Ala (A)). Upon increasing the $\mathrm{pH}$, first, the relative intensity of the singlet at $3.35 \mathrm{ppm}$ increases up to $\mathrm{pH}$ ca. 4.5 and then starts to decrease and disappears by $\mathrm{pH}$ ca. 7 . This suggests the displacement of the hydroxamate from the coordination sphere by $\mathrm{pH} 7$, and, since the non-complexed hydroxamic function exists in its protonated form below and ca. $\mathrm{pH} 7$, protonation of the displaced hydroxamate function occurs (a significant increase is seen in the intensity of the singlet at $3.22 \mathrm{ppm}$ above $\mathrm{pH} 7)$. The appearance of a new doublet $(1.55 \mathrm{ppm})$ at $\mathrm{pH}=3.21$ indicates the formation of a new species (this should be $\left[\mathrm{M}_{2} \mathrm{~L}\right]^{2+}$ ), in which the hydroxamate chelate still exists, but the $\mathrm{NH}_{2}$-function is also coordinated to another half-sandwich cation, most probably together with the neighbouring carbonyl-O. A new doublet at $1.30 \mathrm{ppm}$ appears at $\mathrm{pH}$ ca. 4.5. Its relative intensity shows a sharp increase upon increasing the $\mathrm{pH}$ from 4.5 to 5.5 , and some additional increase up to $\mathrm{pH}$ ca. 7.5 is observable, too. This signal starts to broaden, and its relative intensity decreases above $\mathrm{pH}$ ca. 8 but remains in the spectra up to as high as $\mathrm{pH} 9.8$. Consumption of three equivalents of base and existence of three different species are shown in Figure $7 \mathrm{a}, \mathrm{c}$ respectively, within the $\mathrm{pH}$-range, where the doublet at $1.30 \mathrm{ppm}$ exists. The three species, which are formed within the mentioned $\mathrm{pH}$-range are the $\left[\mathrm{M}_{2} \mathrm{H}_{-1} \mathrm{~L}\right]^{2+},\left[\mathrm{ML}^{+}\right.$, and $\left[\mathrm{MH}_{-} \mathrm{L}\right]$. As it is evident from the above NMR results, the coordination mode of the amino terminus of the tripeptide derivative in these three complexes is similar to each other and occurs, most probably, via $\left(\mathrm{NH}_{2}, \mathrm{~N}_{\text {amide, }} \mathrm{CO}\right)$. The differences between the coordination modes of these complexes are due to the $\mathrm{C}$-terminal end, where the hydroxamic function is situated. This latter function is deprotonated and coordinated to a second metal ion in $\left[\mathrm{M}_{2} \mathrm{H}_{-1} \mathrm{~L}\right]^{2+}$, it is non-coordinated and protonated in $[\mathrm{ML}]^{+}$(the formula of this species is in fact $\left.\left[\mathrm{MH}\left(\mathrm{H}_{-1} \mathrm{~L}\right)\right]^{+}\right)$, while it is non-coordinated and deprotonated in $\left.\left[\mathrm{MH}_{-1} \mathrm{~L}\right]\right)$. (The deprotonation of the 
non-coordinated hydroxamic function is clearly seen in Figure $8 \mathrm{a}$ from the upfield shift of the resonance of the N-methyl singlet (E) from $3.22 \mathrm{ppm}$ to $3.10 \mathrm{ppm}$ between $\mathrm{pH}$ ca. 7-9.) The thermodynamically most stable complex, $\left[\mathrm{MH}_{-2} \mathrm{~L}\right]^{-}$, in this system is present above $\mathrm{pH} 8$ with the coordination mode of $\left(\mathrm{NH}_{2}, \mathrm{~N}_{\text {amide, }}, \mathrm{N}_{\text {amide }}\right)$, via two joined five-membered chelates.

Compared to the secondary derivative, the primary counterpart AlaGlyGlyNHOH has an additional and strong competitor donor, $\mathrm{N}_{\text {hydr }}$ in its deprotonated form. Consequently, in this ligand, the number of the $\mathrm{N}$-donors, which can be in chelatable position to each other, is four $\left(\mathrm{NH}_{2}\right.$, two $\left.\mathrm{N}_{\text {amides }}, \mathrm{N}_{\text {hydr }}\right)$, which is more than enough to saturate the three available coordination sites of $\left[\left(\eta^{5}-\mathrm{Cp} \mathrm{p}^{*}\right) \mathrm{Rh}\left(\mathrm{H}_{2} \mathrm{O}\right)_{3}\right]^{2+}$. Although this results in higher variation of the binding modes with the primary ligand compared to the secondary one no difference can be seen between their coordination behaviour at the start of the interaction ( $\mathrm{pH}$ ca. 2-3), where the $(\mathrm{O}, \mathrm{O})_{\text {hydr }}$ dominates with both ligands and also the thermodynamically most stable complex, $\left[\mathrm{MH}_{-2} \mathrm{~L}\right]^{-}$, has the same binding mode $\left(\mathrm{NH}_{2}, \mathrm{~N}_{\text {amide }}, \mathrm{N}_{\text {amide }}\right)$ in both cases. The formation of $\left[\mathrm{MH}_{-2} \mathrm{~L}\right]^{-}(c f$. Figure $7 \mathrm{c}, \mathrm{d})$, however, is somewhat hindered with the primary derivative (its formation $\mathrm{pH}$ is above 9) compared to the secondary one ( $\mathrm{pH} \sim 8)$. This difference clearly supports the importance of the $\mathrm{N}_{\text {hydr }}$ coordination in the intermediate $\mathrm{pH}$-range with AlaGlyGlyNHOH. The most important role of this donor is indicated by the NMR spectra (Figure $8 \mathrm{~b}$ ) in the pH-range ca. 7-10.5, where a new doublet at high field (1.18 ppm) exists. The $\mathrm{pH}$-dependence of its intensity is very similar to the concentration profile of $\left[\mathrm{MH}_{-1} \mathrm{~L}\right]$ ( $c f$. Figures $7 \mathrm{~d}$ and $8 \mathrm{~b}$ ) suggesting that this signal can be designated to the latter complex, in which, most probably, three nitrogens are coordinated to the metal cation $\left(\mathrm{NH}_{2}, \mathrm{~N}_{\text {amide, }}, \mathrm{N}_{\text {hydr }}\right)$. The differences between the binding modes in $\left[\mathrm{MH}_{-1} \mathrm{~L}\right]$ formed with AlaGlyGlyN(Me)OH and AlaGlyGlyNHOH are well observable by the comparison of structures XII and XIII in Scheme 6.

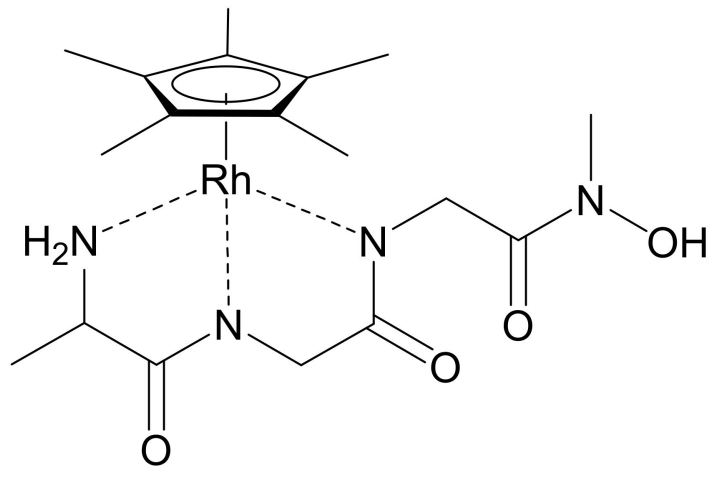

XII

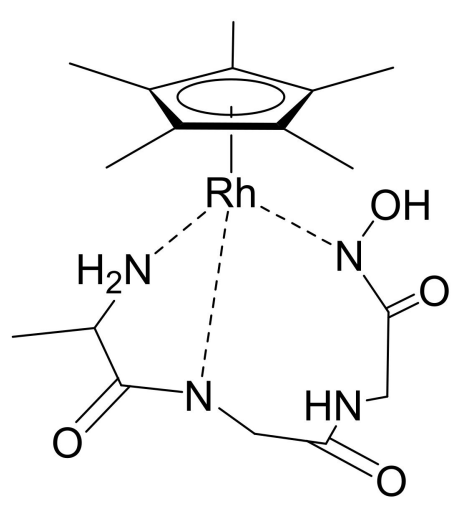

XIII

Scheme 6. Suggested binding modes for the $\left[\mathrm{MH}_{-1} \mathrm{~L}\right]$ complexes formed in the $\left[\left(\eta^{5}-\mathrm{C} \mathrm{p}^{*}\right) \mathrm{Rh}\left(\mathrm{H}_{2} \mathrm{O}\right)_{3}\right]^{2+}-$ AlaGlyGlyN(Me)OH (structure XII) and $\left[\left(\eta^{5}-\mathrm{Cp}^{*}\right) \mathrm{Rh}\left(\mathrm{H}_{2} \mathrm{O}\right)_{3}\right]^{2+}-\mathrm{AlaGlyGlyNHOH}$ (structure XIII) systems.

\section{Discussion}

Based on the solution equilibrium results and on the comparison of them, the following conclusions can be drawn regarding the complexes of primary and secondary hydroxamic derivatives of common di- and tripeptides, AlaAlaNHOH, AlaAlaN(Me)OH, AlaGlyGlyNHOH, and AlaGlyGlyN(Me)OH, with selected $3 d$ metals, $\mathrm{Fe}(\mathrm{III}), \mathrm{Ni}(\mathrm{II}), \mathrm{Cu}(\mathrm{II}), \mathrm{Zn}(\mathrm{II})$, and $4 d$ metals, tetraoxido anion of $\mathrm{Mo}(\mathrm{VI})$, half-sandwich type cations of $\mathrm{Ru}(\mathrm{II})$ and $\mathrm{Rh}(\mathrm{III}),\left[\left(\eta^{6}-p-\mathrm{cym}\right) \mathrm{Ru}\left(\mathrm{H}_{2} \mathrm{O}\right)_{3}\right]^{2+}$, and $\left[\left(\eta^{5}-\mathrm{C} \mathrm{p}^{*}\right) \mathrm{Rh}\left(\mathrm{H}_{2} \mathrm{O}\right)_{3}\right]^{2+}$ :

1. Due to its highest conditional stability out of the possible ones under highly acidic conditions, the hydroxamate-type chelate, $(\mathrm{O}, \mathrm{O})_{\text {hydr }}$ is the anchor with all the studied metal ions, $\mathrm{Mo}(\mathrm{VI})$, $\mathrm{Fe}(\mathrm{III}), \mathrm{Cu}(\mathrm{II}), \mathrm{Ru}(\mathrm{II})$, and $\mathrm{Rh}(\mathrm{III})$, with which the interaction starts at $\mathrm{pH}$ ca. 3 or below. The situation is somewhat different with $\mathrm{Ni}(\mathrm{II})$ and $\mathrm{Zn}(\mathrm{II})$, where the interaction starts at $\mathrm{pH}$ ca. 4 or somewhat above. In these latter systems, binding isomers can exist because the coordination starts either via the five-membered $(\mathrm{O}, \mathrm{O})_{\text {hydr }}$ or five-membered $\left(\mathrm{NH}_{2}, \mathrm{CO}\right)$ chelate. For $\mathrm{Zn}(\mathrm{II})$, 
these initial interactions were followed by hydrolytic processes resulting in the formation of mixed hydroxido complexes.

2. Exclusive hydroxamate-type coordination could be detected in the whole pH-range with Fe(III) and $\mathrm{Mo}(\mathrm{VI})$ (or also hydroximate-type one in the case of $\mathrm{Mo}(\mathrm{VI})$ with primary derivatives at higher $\mathrm{pH}$ ). No role of the amino-N or peptide amide-N(s) was found in the complexation with these two metals. Consequently, there is no any significant difference between their complexation with the studied dipeptide and tripeptide derivatives. However, significant difference was found between the $\mathrm{Mo}(\mathrm{VI})$-binding ability of the primary and secondary derivatives, the former being much more effective $\mathrm{Mo}(\mathrm{VI})$-chelators. This is due to the significantly higher stability of the doubly deprotonated hydroximato chelate (which was detected in the $\mathrm{Mo}(\mathrm{VI})$-primary derivative ligand systems up to $\mathrm{pH}$ ca. 10). On the contrary, the mono-deprotonated $(\mathrm{O}, \mathrm{O})_{\text {hydr }}$ chelate cannot compete with the hydrolysis of the $\mathrm{Mo}(\mathrm{VI})$ above the neutral $\mathrm{pH}$.

3. Out of the investigated metals, $\mathrm{Ni}$ (II) showed the highest preference towards the $\mathrm{N}$-donors over the hydroxamate oxygens. This allows only a minor role of the $(\mathrm{O}, \mathrm{O})_{\text {hydr }}$ at the beginning of the interaction. After that, $\mathrm{Ni}(\mathrm{II})$ forms with the primary AlaGlyGlyNHOH in slow cooperative processes a planar, $4 \mathrm{~N}$-coordinated $\left(\mathrm{NH}_{2}, \mathrm{~N}_{\text {amide, }}, \mathrm{N}_{\text {amide, }}, \mathrm{N}_{\text {hydr }}\right)$ 1:1 complex with very high stability, which exclusively exists above $\mathrm{pH}$ ca. 6. With the secondary counterpart, however, an $\left(\mathrm{NH}_{2}, \mathrm{~N}_{\text {amide }}, \mathrm{N}_{\text {amide}}, \mathrm{O}_{\text {hydr }}\right)$-coordinated planar complex is formed, with slightly lower stability and dominates only above $\mathrm{pH}$ ca. 7 . The hydrolysis of the coordinated metal ion is hindered in both complexes, but, in the latter system, formation of bis-complexes in small extent can be observed in the presence of ligand excess. Nevertheless, even the secondary AlaGlyGlyN(Me)OH is a more effective ligand for $\mathrm{Ni}(\mathrm{II})$ (the situation is the same with $\mathrm{Cu}(\mathrm{II})$ ) than the previously studied dipeptide derivatives $[19,20]$.

4. Although the binding modes of the most stable $\mathrm{Cu}(\mathrm{II})$ complexes with AlaGlyGlyNHOH and with the secondary counterpart, the $4 \mathrm{~N}$-coordinated $\left(\mathrm{NH}_{2}, \mathrm{~N}_{\text {amide, }} \mathrm{N}_{\text {amide, }} \mathrm{N}_{\text {hydr }}\right)$ and $\left(\mathrm{NH}_{2}, \mathrm{~N}_{\text {amide }}, \mathrm{N}_{\text {amide }}, \mathrm{O}_{\text {hydr }}\right)$ planar 1:1 complexes, respectively, are the same as those with $\mathrm{Ni}(\mathrm{II})$; moreover their stability constants are significantly higher than those of the corresponding $\mathrm{Ni}(\mathrm{II})$ complexes (see Table 2), these species become predominant in the $\mathrm{Cu}(\mathrm{II})$-containing systems in the higher $\mathrm{pH}$-range only (above $\mathrm{pH} 8$ and 9 , respectively). This happens because the $(\mathrm{O}, \mathrm{O})_{\text {hydr }}$ can play a crucial role in the interaction with $\mathrm{Cu}(\mathrm{II})$, and this is not the case for $\mathrm{Ni}(\mathrm{II})$. As a result of the measurable competition between the different types of potential donors even at neutral $\mathrm{pH}$, the processes become very slow especially in the $\mathrm{Cu}$ (II)-primary tripeptide derivative system (too slow to allow conventional titrimetry). There is some dominance of the formation of oligonuclear (mostly dimeric or trimeric) complexes and, mainly with the secondary derivative, the formation of bis-hydroxamato intermediate complexes is also considerable.

5. There are only maximum three sites available for coordination for the studied half-sandwich type $\mathrm{Ru}(\mathrm{II})$ and $\mathrm{Rh}(\mathrm{III})$ cations. There is no doubt that with both cations and all four ligands the $(\mathrm{O}, \mathrm{O})_{\text {hydr }}$ anchor-chelate can remain in the coordination sphere up to $\mathrm{pH}$ ca. 7 but is displaced by nitrogen donors, if there is no possibility for the formation of the hydroximate- $(\mathrm{O}, \mathrm{O})$ chelate, with the doubly deprotonated hydroxamic function. If, however, it can be formed, it remains in the coordination sphere, which is the case with the primary dipeptide derivative AlaAlaNHOH, and the N-donors can only coordinate to another metal ion. Consequently, dinuclear complexes predominate from slightly acidic conditions until the end of the investigated $\mathrm{pH}$-range with both cations. In the most stable complex, the donor set $\left(\mathrm{NH}_{2}, \mathrm{~N}_{\text {amide, }}, \mathrm{N}_{\text {hydr }}\right)$ saturates the coordination sites of one metal, while the $(\mathrm{O}, \mathrm{O})_{\text {hydr }}$ chelate and either a water, or above $\mathrm{pH}$ ca. 9-10, a hydroxide ion binds to another metal ion. On the contrary, mononuclear complexes dominate with the secondary counterpart, AlaAlaN(Me)OH, being the most stable an $\left(\mathrm{NH}_{2}, \mathrm{~N}_{\text {amide, }}, \mathrm{O}_{\text {hydr }}\right)$-coordinated complex with the $\left[\left(\eta^{5}-\mathrm{Cp}^{*}\right) \mathrm{Rh}\left(\mathrm{H}_{2} \mathrm{O}\right)_{3}\right]^{2+}$ cation. Due to the significantly higher affinity of $\left[\left(\eta^{6}-p-c y m\right) \mathrm{Ru}\left(\mathrm{H}_{2} \mathrm{O}\right)_{3}\right]^{2+}$ toward hydrolysis, it forms a mixed hydroxido complex involving an $\left(\mathrm{NH}_{2}, \mathrm{~N}_{\text {amide }}\right)$ chelate and a monodentate $\mathrm{OH}^{-}$. 
6. The complex formation processes were too slow between $\left[\left(\eta^{6}-p \text {-cym }\right) \mathrm{Ru}\left(\mathrm{H}_{2} \mathrm{O}\right)_{3}\right]^{2+}$ and the two tripeptide derivatives, AlaGlyGlyNHOH and AlaGlyGlyN(Me)OH, above $\mathrm{pH}$ ca. 6, where the interaction with the $\mathrm{N}$-donors started. Consequently, solution equilibrium measurements were possible only on the $\left[\left(\eta^{5}-\mathrm{Cp}^{*}\right) \mathrm{Rh}\left(\mathrm{H}_{2} \mathrm{O}\right)_{3}\right]^{2+}$-containing systems. With the secondary derivative containing three potential nitrogen donors, the initial $(\mathrm{O}, \mathrm{O})_{\text {hydr }}$ chelate in the highly acidic $\mathrm{pH}$ range is partially replaced by the coordination of the $\mathrm{NH}_{2}$ group (most probably together with the neighboring $\mathrm{CO}$ ) above $\mathrm{pH}$ ca. 4. This results in the formation of dinuclear species with mixed $(\mathrm{O}, \mathrm{O})_{\text {hydr }}$ and $\left(\mathrm{NH}_{2}, \mathrm{CO}\right)$ coordination below $\mathrm{pH}$ ca. 7-7.5 as minor complexes, but mononuclear species with $\left(\mathrm{NH}_{2}, \mathrm{~N}_{\text {amide, }}, \mathrm{N}_{\text {amide }}\right)$ binding mode (having the hydroxamate function is uncoordinated) dominate even in this intermediate $\mathrm{pH}$-range.

7. The primary AlaGlyGlyNHOH contains four potential N-donors, which is more than enough to saturate the coordination sphere of a $\left[\left(\eta^{5}-\mathrm{Cp}^{*}\right) \mathrm{Rh}\left(\mathrm{H}_{2} \mathrm{O}\right)_{3}\right]^{2+}$ cation. The results show a measurable competition between the C-terminal $\mathrm{N}_{\text {amide }}$ and $\mathrm{N}_{\text {hydr }}$ between $\mathrm{pH}$ ca. 7-10, but above this $\mathrm{pH}$, the complex with the $\left(\mathrm{NH}_{2}, \mathrm{~N}_{\text {amide, }}, \mathrm{N}_{\text {amide }}\right)$ donor set, containing the hydroxamate function in uncoordinated form, has increasing dominance.

\section{Materials and Methods}

\subsection{Materials and Stock Solutions}

The ligands AlaAlaNHOH, AlaAlaN(Me)OH, AlaGlyGlyNHOH, and AlaGlyGlyN(Me)OH were synthesized as previously described [19-21]. The purity and the exact concentration of the ligand stock solutions were determined by $\mathrm{pH}$-potentiometry using the Gran's method [33].

The metal ion stock solutions were prepared from $\mathrm{CuCl}_{2} \cdot 2 \mathrm{H}_{2} \mathrm{O}, \mathrm{NiCl}_{2} \cdot 5 \mathrm{H}_{2} \mathrm{O}, \mathrm{FeCl}_{3} \cdot 6 \mathrm{H}_{2} \mathrm{O}$, and $\mathrm{Na}_{2} \mathrm{MoO}_{4}$ (Reanal, Hungary) using doubly deionised and ultra-filtered water obtained from a Milli-Q RG (Millipore, Burlington, MA, USA) water purification system. In the case of $\mathrm{Fe}(\mathrm{III})$, the stock solution also contained hydrochloric acid $(\sim 0.1 \mathrm{M})$. ZnO (Reanal, Hungary) was dissolved in diluted $\mathrm{HCl}$ to prepare $\mathrm{Zn}(\mathrm{II})$ stock solution. The metal ion concentrations were checked gravimetrically via precipitation of the quinolin-8-olate salts, $\mathrm{Fe}(\mathrm{III})$ was determined by complexometric titration. The acid content of the $\mathrm{Fe}$ (III) stock solution was also estimated using the Gran's method [33].

$\mathrm{RuCl}_{3} \cdot \mathrm{xH}_{2} \mathrm{O}, \alpha$-terpinene were purchased from Aldrich (St. Louis, MO, USA), and [( $\left.\eta^{5}-\mathrm{Cp} \mathrm{p}^{*}\right) \mathrm{Rh}\left(\mu^{2}-\right.$ $\mathrm{Cl}) \mathrm{Cl}_{2}$ was a commercial product from Strem Chemicals (Newburyport, MA, USA). These chemicals were used without further purification. $\left[\left(\eta^{6}-p-c y m\right) \mathrm{Ru}\left(\mu^{2}-\mathrm{Cl}\right) \mathrm{Cl}\right]_{2}$ was synthesized and purified according to a literature method [34]. The aqueous solutions of $\left[\left(\eta^{6}-p\right.\right.$-cym $\left.) \mathrm{Ru}\left(\mathrm{H}_{2} \mathrm{O}\right)_{3}\right]\left(\mathrm{NO}_{3}\right)_{2}$ and $\left[\left(\eta^{5}-\mathrm{Cp}^{*}\right) \mathrm{Rh}\left(\mathrm{H}_{2} \mathrm{O}\right)_{3}\right]\left(\mathrm{NO}_{3}\right)_{2}$ were obtained by removal the chloride ions from the corresponding dimers using stoichiometric amount of $\mathrm{AgNO}_{3}$. Metal ion and proton concentrations of these metal ion stock solutions were also checked with the aid of potentiometric titrations.

Carbonate-free $\mathrm{KOH}$ solutions of known concentrations (ca. $0.2 \mathrm{M}$ during the pH-metric measurements and ca. $5 \mathrm{M}$ to adjust the $\mathrm{pH}$ during the ${ }^{17} \mathrm{O}-\mathrm{NMR}$ ) were used as titrant. $\mathrm{HCl}$ and $\mathrm{HNO}_{3}$ stock solutions were prepared from their concentrated solutions (both acids and the base were Merck products, Germany), and their concentrations were determined by $\mathrm{pH}$-metric titrations.

\subsection{Solution Studies}

For all of the solution studies, doubly deionised and ultra-filtered water was obtained from a Milli-Q RG (Millipore) water purification system.

$\mathrm{pH}$ potentiometric measurements were carried out at $25.0 \pm 0.1^{\circ} \mathrm{C}$, at an ionic strength of $0.20 \mathrm{M}$ $\mathrm{KNO}_{3}$ if the metal ion was either $\left[\left(\eta^{6}-p \text {-cym }\right) \mathrm{Ru}\left(\mathrm{H}_{2} \mathrm{O}\right)_{3}\right]^{2+}$ or $\left[\left(\eta^{5}-\mathrm{Cp}^{*}\right) \mathrm{Rh}\left(\mathrm{H}_{2} \mathrm{O}\right)_{3}\right]^{2+}$, while in all the other cases, it was at $0.20 \mathrm{M} \mathrm{KCl}$. For the systems containing $\mathrm{Ru}(\mathrm{II})$ or $\mathrm{Rh}(\mathrm{III})$ and a dipeptide hydroxamic acid as ligand a Mettler Toledo (Switzerland) T50 titrator, if, however, the ligand was a tripeptide hydroxamic acid, a Mettler Toledo DL50 titrator was used for the $\mathrm{pH}$-metric titrations. Both instruments were equipped with a Metrohm (Switzerland) double junction (6.0255.100) combined electrode. In all the other 
cases a Radiometer pHM 84 instrument equipped with Metrohm combined electrode (type 6.0234.100) and Metrohm 715 Dosimat burette was used for the pH-metry. The electrode systems were calibrated according to Irving et al. [35]. Therefore, the $\mathrm{pH}$-meter readings could be converted into hydrogen ion concentrations. The water ionization constant was $\mathrm{p} K_{\mathrm{w}}=13.75 \pm 0.01$ under the experimental conditions used. The initial volumes of the samples were 5.00, 10.00, or $15.00 \mathrm{~mL}$, and the ligand concentrations were varied in the range of $1-5 \mathrm{mM}$ and the metal ion to ligand ratios between 2:1-1:5. Typically, three to five ratios were measured in each system. The samples were stirred and completely deoxygenated by bubbling purified argon. Titrations were performed in the $\mathrm{pH}$-range of 2.0-11.0 or until precipitation occurred in equilibrium controlled mode. $\mathrm{pH}$ equilibrium was assumed to be reached if a change in the measured potential was less than $0.01 \mathrm{mV}$ within $11 \mathrm{~s}$ and $0.1 \mathrm{mV}$ within $90 \mathrm{~s}$ for the Mettler Toledo DL50 and Mettler Toledo T50 titrators, respectively. The maximum waiting time for the metal ion-containing systems was $10 \mathrm{~min}$ in general, except the systems containing $\mathrm{Ru}(\mathrm{II})$ or $\mathrm{Rh}(\mathrm{III})$ half-sandwich cations, where it was $30 \mathrm{~min}$ due to the quite slow equilibrium processes. If the equilibrium was not reached within these times, the measured value was not used during the calculation.

In general, the overall stability constants calculated for the complexes relate to the equilibrium

$$
\begin{gathered}
\mathrm{pM}+\mathrm{qH}+\mathrm{rL} \rightleftharpoons\left[\mathrm{M}_{\mathrm{p}} \mathrm{H}_{\mathrm{q}} \mathrm{L}_{\mathrm{r}}\right] \\
\beta_{\mathrm{pqr}}=\left[\mathrm{M}_{\mathrm{p}} \mathrm{H}_{\mathrm{q}} \mathrm{L}_{\mathrm{r}}\right] /[\mathrm{M}]^{\mathrm{p}}[\mathrm{H}]^{\mathrm{q}}[\mathrm{L}]^{\mathrm{r}}
\end{gathered}
$$

where " $\mathrm{M}^{\prime \prime}$ stands for $\mathrm{Fe}^{3+}, \mathrm{Ni}^{2+}, \mathrm{Cu}^{2+}, \mathrm{Zn}^{2+},\left[\left(\eta^{6}-p \text {-cym }\right) \mathrm{Ru}\left(\mathrm{H}_{2} \mathrm{O}\right)_{3}\right]^{2+}$, or $\left[\left(\eta^{5}-\mathrm{Cp}^{*}\right) \mathrm{Rh}\left(\mathrm{H}_{2} \mathrm{O}\right)_{3}\right]^{2+}$ and " $\mathrm{L}$ " represents the completely deprotonated forms of the ligands. Because the charges are not always the same, they are omitted in Equation (5).

In the case of $\mathrm{Mo}(\mathrm{VI})$, however, the calculated stability constants refer to Equation (1) given in Section 2.3.

In all calculations, the stability constants were determined via fitting the titration curves by using the PSEQUAD and SUPERQUAD programs [36,37]. In the case of the systems, where measurable competition between the hydrolysis of the metal ions and the complexation processes can occur, the former was taken into account during the calculations by using the following literature data (where the Davies equation was used to take into account the different ionic strengths; negative stoichiometric number of $\mathrm{H}$ relates to the metal induced ionization of the coordinated water).

$$
\begin{aligned}
& {[\mathrm{Fe}(\mathrm{OH})]^{2+} \log \beta_{1,-1,0}=-3.21 ;\left[\mathrm{Fe}(\mathrm{OH})_{2}\right]^{+} \log \beta_{1,-2,0}=-6.73 ;\left[\mathrm{Fe}_{2}(\mathrm{OH})_{2}\right]^{4+} \log \beta_{2,-2,0}=4.09 ;} \\
& {\left[\mathrm{Fe}_{3}(\mathrm{OH})_{4}\right]^{5+} \log \beta_{3,-4,0}=-7.58[38] .} \\
& {\left[\mathrm{HMoO}_{4}\right]^{-} \log \beta_{1,1,0}=4.03 ;\left[\mathrm{H}_{2} \mathrm{MoO}_{4}\right] \log \beta_{1,2,0}=6.70 ;\left[\mathrm{H}_{8}\left(\mathrm{MoO}_{4}\right)_{7}\right]^{6-} \log \beta_{7,8,0}=53.18 ;} \\
& {\left[\mathrm{H}_{9}\left(\mathrm{MoO}_{4}\right)_{7}\right]^{5-} \log \beta_{7,9,0}=58.10 ;\left[\mathrm{H}_{10}\left(\mathrm{MoO}_{4}\right)_{7}\right]^{4-} \log \beta_{7,10,0}=62.11 ;\left[\mathrm{H}_{11}\left(\mathrm{MoO}_{4}\right)_{7}\right]^{3-} \log \beta_{7,11,0}} \\
& =64.54[30] . \\
& {\left[\left\{\left(\eta^{6}-p-\mathrm{cym}\right) \mathrm{Ru}\right\}_{2}\left(\mu^{2}-\mathrm{OH}\right)_{3}\right]^{+}\left(\log \beta_{2,-3,0}=-9.16\right)[32]} \\
& {\left[\left\{\left(\eta^{5}-\mathrm{Cp} \mathrm{p}^{*}\right) \mathrm{Rh}\right\}_{2}\left(\mu^{2}-\mathrm{OH}\right)_{2}\right]^{2+}\left(\log \beta_{2,-2,0}=-8.53\right) ;\left[\left\{\left(\eta^{5}-\mathrm{Cp}^{*}\right) \mathrm{Rh}\right\}_{2}\left(\mu^{2}-\mathrm{OH}\right)_{3}\right]^{+} \quad\left(\log \beta_{2,-3,0}=\right.} \\
& -14.26)[39] .
\end{aligned}
$$

For the $\mathrm{Ru}-\mathrm{AlaAlaNHOH}$ system (where $\mathrm{Ru}$ stands for $\left[\left(\eta^{6}-p \text {-cym) } \mathrm{Ru}\left(\mathrm{H}_{2} \mathrm{O}\right)_{3}\right]^{2+}\right.$ ), the corresponding hydrochloride salt of the ligand was used, therefore the studied samples also contain one equivalent of chloride ion as a second ligand.

${ }^{1} \mathrm{H}-\mathrm{NMR}$ titrations were carried out on a Bruker (Billerica, MA, USA) Avance 400 instrument at $25.0{ }^{\circ} \mathrm{C}$ at an ionic strength of $0.20 \mathrm{M} \mathrm{KNO}_{3}$ for the systems containing $\mathrm{Ru}$ (II) or Rh(III) half-sandwich cations and on a Bruker AM360 FT NMR instrument at $0.20 \mathrm{M} \mathrm{KCl}$ for the systems containing Zn(II) or $\mathrm{Mo}(\mathrm{VI})$. The chemical shifts are reported in ppm $\left(\delta_{\mathrm{H}}\right)$ from TSP as internal standard. Titrations were performed using individual samples equilibrated for 1 hour prior to the measurements in $\mathrm{D}_{2} \mathrm{O}(99.8 \%)$ at $c_{L}=10.0 \mathrm{mM}$ in the case of dipeptide hydroxamic acid containing systems and $\mathrm{c}_{\mathrm{L}}=5.0 \mathrm{mM}$ for the tripeptide hydroxamic acid containing ones. The metal ion to ligand ratios were $1: 1$ and $2: 1$, the $\mathrm{pH}$ 
of the samples was varied in the range of 2.0-11.5. The $\mathrm{pH}$ of the samples was set up with $\mathrm{NaOD}$ or $\mathrm{DNO}_{3}$ solutions in $\mathrm{D}_{2} \mathrm{O}$. The $\mathrm{pH}^{*}$ values ( $\mathrm{pH}$ meter readings in $\mathrm{D}_{2} \mathrm{O}$ solution of a $\mathrm{pH}$-meter calibrated in $\mathrm{H}_{2} \mathrm{O}$ according to Irving et al. [35]) were converted into $\mathrm{pH}$ values using the following equation: $\mathrm{pH}=0.936 \times \mathrm{pH}^{*}+0.412$. [40].

On all the other systems, the ${ }^{1} \mathrm{H}-\mathrm{NMR}$ measurements were made on Bruker AM 360 by using $\mathrm{D}_{2} \mathrm{O}$ as solvent. For $\mathrm{Mo}(\mathrm{VI})$, DSS was used as standard, metal to ligand ratio was 1:3 in all samples, the analytical concentration of the ligand was $0.015 \mathrm{M}$.

For the $\mathrm{Mo}(\mathrm{VI})$-containing systems, ${ }^{17} \mathrm{O}-\mathrm{NMR}$ measurements were performed at 1:3 metal ion to ligand ratio at $\mathrm{c}_{\mathrm{L}}=0.15 \mathrm{M}$. The solvent was $90 \% \mathrm{H}_{2} \mathrm{O} 10 \% \mathrm{D}_{2} \mathrm{O}$ enriched for ${ }^{17} \mathrm{O}$. Enrichment of the molybdate oxygen atoms to $3 \%$ was done by the addition of $\mathrm{H}_{2}{ }^{17} \mathrm{O}(37.8 \%$, ISOTEC Inc., Matheson $\mathrm{CO}, \mathrm{USA}$ ) to the samples. The enrichment included the $\mathrm{M}=\mathrm{O}$ oxygens, while the oxygens of the ligands were not involved in the ${ }^{17} \mathrm{O}$ isotope enrichment, being inert for oxygen exchange. Spectra were registered on a Bruker DRX 500 NMR equipment at $67.8 \mathrm{MHz}$. Spectral widths of $1200 \mathrm{ppm}$ $(81.4 \mathrm{kHz})$ were used, and data for the FID were accumulated in $8 \mathrm{k}$ blocks. A $40^{\circ}$ pulse angle and $100 \mathrm{~ms}$ relaxation delays were used. The spectra were integrated after baseline correction by using WINNMR 960901 software. Chemical shifts refer to the signal of tap water, $\delta=0 \mathrm{ppm}$.

Frozen solution EPR (Electron Paramagnetic Resonance) spectra in aqueous samples of the copper complexes were recorded on a Bruker EMX X-band spectrometer, operating at $\sim 9.4 \mathrm{GHz}$, equipped with a HP 53150A microwave frequency counter using ${ }^{63} \mathrm{CuSO}_{4}$ stock solution. Metallic copper was purchased from JV Isoflex (Moscow, Russia) containing $99.3 \%{ }^{63} \mathrm{Cu}$ and $0.7 \%{ }^{65} \mathrm{Cu}$ and converted into the sulfate. The samples for low-temperature measurements contained a few drops of ethylene glycol to ensure good glass formation. The metal ion to ligand ratios varied in the range 1:1-1:5 and $\mathrm{c}_{\mathrm{Cu} \text { (II) was }}$ $0.005 \mathrm{M}$; the $\mathrm{pH}$ of the samples was varied in the range of 3.4-10.2. Increasing the resolution and avoid the aggregation process $10 \%$ ethylene glycol was added to the aqueous copper(II) complex samples.

An HP 8453 or Perkin Elmer Lambda 25 spectrophotometer was used to record the UV-Vis spectra over the range $250-800 \mathrm{~nm}$ for copper(II)-, iron(III)-, and nickel(II)-containing systems. The path length was $1 \mathrm{~cm}$. Measurements for the iron(III)-containing samples were carried out on individual samples in which the $0.20 \mathrm{M} \mathrm{KCl}$ was partially or completely replaced by $\mathrm{HCl}$. $\mathrm{pH}$ values, varying in the range ca. 0.7-1.6, were calculated from the $\mathrm{HCl}$ content. The metal ion concentrations were in the range 0.0004-0.0008 $\mathrm{M}$, and the metal ion to ligand ratios were in the range 1:1-1:5. Spectrophotometric titrations were also performed with samples containing $\mathrm{Fe}(\mathrm{III}), \mathrm{Cu}(\mathrm{II})$ or $\mathrm{Ni}$ (II) in $0.0004-0.004 \mathrm{M}$ concentrations at metal to ligand ratios ranging from 1:1 to 1:5. The spectrophotometric results were utilized to calculate the stability constants for the Fe(III) complexes formed below pH 2.0.

ESI-MS measurements were carried out on a Bruker micrOTOF-Q instrument in positive ion mode. The samples were prepared in water, at $\mathrm{c}_{\mathrm{M}}=0.3 \mathrm{mM}$. The metal ion to ligand ratios were 1:1 and 2:1 in all cases, the $\mathrm{pH}$ of the samples was set up according to the concentration distribution curves by using $\mathrm{HNO}_{3}$ or $\mathrm{KOH}$ solutions. The temperature of the drying gas $\left(\mathrm{N}_{2}\right)$ was $180^{\circ} \mathrm{C}$, and the pressure of the nebulizing gas was 0.3 bar. The flow rate was $3 \mu \mathrm{L} / \mathrm{min}$. The spectra were accumulated and recovered by a digitalizer at a sampling rate of $2 \mathrm{GHz}$. DataAnalysis (version 3.4) was used for the calculations.

Supplementary Materials: The following are available online at http:/www.mdpi.com/1420-3049/24/21/3941/ s1: Figure S1. EPR spectra recorded at different $\mathrm{pH}$ values for the (a) ${ }^{63} \mathrm{Cu}(\mathrm{II})-\mathrm{AlaGlyGlyNHOH}$ and (b) ${ }^{63} \mathrm{Cu}(\mathrm{II})-\mathrm{AlaGlyGlyN}(\mathrm{Me}) \mathrm{OH}$ systems at 1:1 and 1:2 metal ion to ligand ratios, respectively $\left(\mathrm{C}_{\mathrm{Cu}} \mathrm{(II)}=5.00 \mathrm{mM}\right)$; Figure S2. $\mathrm{pH}$ dependence on the low-field region of ${ }^{1} \mathrm{H}-\mathrm{NMR}$ spectra of $\left[\left(\eta^{6}-p-\mathrm{cym}\right) \mathrm{Ru}\left(\mathrm{H}_{2} \mathrm{O}\right)_{3}\right]^{2+}-\mathrm{AlaAlaNHOH}$ system at 1:1 metal ion to ligand ratio $\left(c_{\mathrm{L}}=10.0 \mathrm{mM}\right)$; Figure S3. Measured and calculated ESI-MS spectra of $\left[\mathrm{M}_{2} \mathrm{H}_{-2} \mathrm{~L}\right]+$ formed in $\left[\left(\eta^{6}-p \text {-cym }\right) \mathrm{Ru}\left(\mathrm{H}_{2} \mathrm{O}\right)_{3}\right]^{2+}-\mathrm{AlaAlaNHOH}$ system at $\mathrm{pH}=8.01$; Figure $\mathbf{S}$. $\mathrm{pH}$ dependence on the ${ }^{1} \mathrm{H}-\mathrm{NMR}$ spectra of $(\mathbf{a})\left[\left(\eta^{5}-\mathrm{Cp}^{*}\right) \mathrm{Rh}\left(\mathrm{H}_{2} \mathrm{O}\right)_{3}\right]^{2+}-\mathrm{AlaGlyGlyN}(\mathrm{Me}) \mathrm{OH}=2: 1$ system and $(\mathbf{b}) \mathrm{CH}_{3}$ signals of $\mathrm{Cp}^{*}$ ligand at different $\mathrm{pH}$ values (region of the methyl protons is shown with reduced intensity for an easier interpretation); Table S1. Observed and calculated $\mathrm{m} / \mathrm{z}$ values of the species formed in the investigated half-sandwich cation-dipeptide hydroxamic acid systems.

Author Contributions: A.O., L.B., E.M.N., and D.S. performed experimental work and were involved in calculations and evaluation of the data. A.O. wrote the first version of the Materials and Methods part of the paper, 
E.F. and P.B. directed the project, supervised the work. E.F. wrote the draft version of the paper (Introduction, Results, and Discussion), which was corrected and completed by the team of the co-authors.

Funding: This research was funded by the EU, co-financed by the European Regional Development Fund under project GINOP-2.3.2-15-2016-00008, and funded by the Hungarian Scientific Research Fund (OTKA K112317).

Acknowledgments: The authors thank Ildikó Nagy for performing the experimental work on the Mo(VI)containing systems.

Conflicts of Interest: The authors declare no conflict of interest.

\section{References}

1. Codd, R. Traversing the coordination chemistry and chemical biology of hydroxamic acids. Coord. Chem. Rev. 2008, 252, 1387-1408. [CrossRef]

2. Gupta, S.P.; Sharma, A. The Chemistry of Hydroxamic Acids. In Hydroxamic acids: A unique Family of Chemicals with Multiple Biological Activities; Gupta S.P, Ed.; Springer: Berlin, Germany, 2013; pp. 1-17.

3. Albrecht-Gary, A.M.; Crumbliss, A.L. Coordination chemistry of siderophores: thermodynamics and kinetics of iron chelation and release. In Metal Ions in Biological Systems; Sigel, A., Sigel, H., Eds.; Marcel Dekker: New York, NY, USA, 1998; Volume 35, pp. 239-327.

4. Muri, E.M.F.; Nieto, M.J.; Sindelar, R.D.; Williamson, J.S. Hydroxamic acids as pharmacological agents. Curr. Med. Chem. 2002, 9, 1631-1653. [CrossRef] [PubMed]

5. Marmion, C.J.; Parker, J.P.; Nolan, K.B. Hydroxamic acids: An Important Class of Metalloenzyme Inhibitors. In Comprehensive Inorganic Chemistry II: From Elements to Applications, 2nd ed.; Reedijk, J., Poeppelmeier, K.R., Eds.; Elsevier Ltd.: Amsterdam, The Netherlands, 2013; Volume 3, pp. 683-708. [CrossRef]

6. Marmion, C.J.; Murphy, T.; Docherty, J.R.; Nolan, K.B. Hydroxamic acids are nitric oxide donors. Facile formation of ruthenium(II)-nitrosyls and NO-mediated activation of guanylate cyclase by hydroxamic acids. Chem. Commun. 2000, 1153-1154. [CrossRef]

7. Kohli, R. Intra-and intermolecular hydrogen bonding in formohydroxamic acid. In Hydrogen bonding abilities of hydroxamic acid and its isosteres; Anchor Academic Publishing: Hamburg, Germany, 2016; pp. 58-112.

8. Carrott, M.J.; Fox, O.D.; LeGurun, G.; Jones, C.J.; Mason, C.; Taylor, R.J.; Andrieux, F.P.L.; Boxall, C. Oxidation-reduction reactions of simple hydroxamic acids and plutonium(IV) ions in nitric acid. Radiochim. Acta 2008, 96, 333-343. [CrossRef]

9. Farkas, E.; Enyedy, É.A. Interaction between iron(II) and hydroxamic acids: oxidation of iron(II) to iron(III) by desferrioxamine B under anaerobic conditions. J. Inorg. Biochem. 2001, 83, 107-114. [CrossRef]

10. Kurzak, B.; Kozlowski, H.; Farkas, E. Hydroxamic and aminohydroxamic acids and their complexes with metal ions. Coord. Chem. Rev. 1992, 114, 169-2000. [CrossRef]

11. Farkas, E.; Csóka, H.; Bell, G.; Brown, D.A.; Cuffe, L.P.; Fitzpatrick, N.J.; Glass, W.K.; Errington, W.; Kemp, T.J. Oxygen versus nitrogen co-ordination in complexes of $\mathrm{Mo}^{\mathrm{VI}}$ and hydroxamate derivatives of $\alpha$-amino acids: equilibrium, structural and theoretical studies. J. Chem. Soc. Dalton Trans. 1999, 16, 2789-2794. [CrossRef]

12. Parajdi-Losonczi, P.L.; Bényei, A.C.; Kováts, É.; Timári, I.; Muchova Radosova, T.; Novohradsky, V.; Kasparkova, J.; Buglyó, P. $\left[\left(\eta^{6}-p \text {-cymene }\right) \mathrm{Ru}\left(\mathrm{H}_{2} \mathrm{O}\right)_{3}\right]^{2+}$ binding capability of aminohydroxamates $-\mathrm{A}$ solution and solid state study. J. Inorg. Biochem. 2016, 160, 236-245. [CrossRef]

13. Parajdi-Losonczi, P.L.; Buglyó, P.; Skakalova, H.; Kasparkova, J.; Lihi, N.; Farkas, E. Half-sandwich type rhodium(III)-aminohydroxamate complexes: the role of the position of the amino group in metal binding. New J. Chem. 2018, 42, 7659-7670. [CrossRef]

14. Kurzak, B.; Farkas, E.; Glowiak, T.; Kozlowski, H. X-Ray and potentiometric studies on a pentanuclear copper(II) complex with $\beta$-alaninehydroxamic acid. J. Chem. Soc., Dalton Trans. 1991, 2, 163-167. [CrossRef]

15. Tegoni, M.; Remelli, M. Metallacrowns of copper(II) and aminohydroxamates: Thermodynamics of self assembly and host-guest equilibria. Coord. Chem. Rev. 2012, 56, 289-315. [CrossRef]

16. Ostrowska, M.; Fritsky, I.O.; Gumienna-Kontecka, E.; Pavlishchu, A.V. Metallacrown-based compounds: Applications in catalysis, luminescence, molecular magnetism, and adsorption. Coord. Chem. Rev. 2016, 327, 304-332. [CrossRef]

17. Farkas, E.; Kiss, I. Complexes of peptidehydroxamates. Complex formation between transition metals and L-prolyl-L-leucylglycinehydroxamic acid [N-hydroxy-7-methyl-4-oxo-5-(pyrrolidine-2'-carboxamido)-3- 
azaoctanamide] and L-prolyl-L-leucinehydroxamic acid [N-hydroxy-4-methyl-2-(pyrrolidine-2'carboxamido)pentanamide]. J. Chem. Soc. Dalton Trans. 1990, 3, 749-753. [CrossRef]

18. Farkas, E.; Csapó, E.; Buglyó, P.; Damante, C.A.; Di Natale, G. Metal binding ability of histidine-containing peptidehydroxamic acids: Imidazole versus hydroxamate coordination. Inorg. Chim. Acta 2009, 362, 753-762. [CrossRef]

19. Buglyó, P.; Nagy, E.M.; Farkas, E.; Sóvágó, I.; Sanna, D.; Micera, G. New insights into the metal ion-peptidehydroxamate interactions: Metal complexes of primary hydroxamic acid derivatives of common dipeptides in aqueous solution. Polyhedron 2007, 26, 1625-1633. [CrossRef]

20. Buglyó, P.; Nagy, E.M.; Sóvágó, I.; Ozsváth, A.; Sanna, D.; Farkas, E. Metal ion binding capability of secondary (N-methyl) versus primary (N-H) dipeptide hydroxamic acids. Polyhedron 2016, 110, 172-181. [CrossRef]

21. Ozsváth, A.; Farkas, E.; Diószegi, R.; Buglyó, P. Versatility and trends in the interaction between Pd(II) and peptide hydroxamic acids. New. J. Chem. 2019, 43, 8239-8249. [CrossRef]

22. Moore, W.M.; Spilburg, C.A. Purification of human collagenases with a hydroxamic acid affinity column. Biochemistry 1986, 25, 5189-5195. [CrossRef]

23. Melchart, M.; Sadler, P.J. Ruthenium Arene Anticancer Complexes. In Bioorganometallics: Biomolecules, Labeling, Medicine; Jaouen, G., Ed.; John Wiley \& Sons: Hoboken, NJ, USA, 2005; pp. 39-64. [CrossRef]

24. Mészáros, J.P.; Poljarevic, J.M.; Gál, G.T.; May, N.V.; Spengler, G.; Enyedy, É.A. Comparative solution and structural studies of half-sandwich rhodium and ruthenium complexes bearing curcumin and acetylacetone. J. Inorg. Biochem. 2019, 195, 91-100. [CrossRef]

25. Tejada-Jimenez, M.; Chamizo-Ampudia, A.; Calatrava, V.; Galvan, A.; Fernandez, E.; Llamas, A. From the Eukaryotic Molybdenum Cofactor Biosynthesis to the Moonlighting Enzyme mARC. Molecules 2018, 23, 3287. [CrossRef]

26. Leimkühler, S.; Wuebbens, M.M.; Rajagopalan, K.V. The history of the discovery of the molybdenum cofactor and novel aspects of its biosythesis in bacteria. Coord. Chem. Rev. 2011, 255, 1129-1144. [CrossRef] [PubMed]

27. Enyedy, É.A.; Csóka, H.; Lázár, I.; Micera, G.; Garibba, E.; Farkas, E. Effects of side-chain aminonitrogen donor atoms on metal complexation of aminohydroxamic acids: New diaminohydroxamates chelating $\mathrm{Ni}(\mathrm{II})$ more strongly than Fe(III). J. Chem. Soc. Dalton Trans. 2002, 13, 2632-2640. [CrossRef]

28. Yokoi, H. ESP and optical absorption studies of various bis(N-salicylidenealkylaminato)copper(II) complexes with terahedrally-distoted coordination geometry. Bull. Chem. Soc. Japan 1974, 47, 3037-3040. [CrossRef]

29. Yokoi, H.; Addison, A.W. Spectroscopic and redox properties of pseudotetrahedral copper(II) complexes. Their relation to copper proteins. Inorg. Chem. 1977, 16, 1341-1349. [CrossRef]

30. Farkas, E.; Csóka, H.; Tóth, I. New insights into the solution equilibrium of molybdenum(VI)-hydroxamate systems: ${ }^{1} \mathrm{H}$ and ${ }^{17} \mathrm{O}-\mathrm{NMR}$ spectroscopic study of $\mathrm{Mo}(\mathrm{VI})$-desferrioxamine $\mathrm{B}$ and $\mathrm{Mo}(\mathrm{VI})$-monohdroxamic acid systems. Dalton Trans. 2003, 8, 1645-1652. [CrossRef]

31. Buglyo, P.; Parajdi-Losonczi, P.L.; Benyei, A.C.; Lihi, N.; Biro, L.; Farkas, E. Versatility of Coordination Modes in Complexes of Monohydroxamic Acids with Half-Sandwich Type Ruthenium, Rhodium, Osmium and Iridium Cations. Chem. Select 2017, 26, 8127-8136. [CrossRef]

32. Bíró, L.; Farkas, E.; Buglyó, P. Hydrolytic behaviour and chloride ion binding capability of $\left[\mathrm{Ru}\left(\eta^{6}-p-c y m\right)\left(\mathrm{H}_{2} \mathrm{O}\right)_{3}\right]^{2+}$ : A solution equilibrium study. Dalton Trans. 2012, 41, 285-299. [CrossRef]

33. Gran, G. Determination of the Equivalent Point in Potentiometric Titrations. Acta Chem. Scand. 1950, 4, 559-577. [CrossRef]

34. Bennett, M.A.; Smith, A.K. Arene ruthenium(II) complexes formed by dehydrogenation of cyclohexadienes with ruthenium(III) trichloride. J. Chem. Soc. Dalton Trans. 1974, 233-241. [CrossRef]

35. Irving, H.M.; Miles, M.G.; Pettit, L.D. A study of some problems in determining the stoicheiometric proton dissociation constants of complexes by potentiometric titrations using a glass electrode. Anal. Chim. Acta 1967, 38, 475-488. [CrossRef]

36. Zékány, I.; Nagypál, I. PSEQUAD: A Comprehensive Program for the Evaluation of Potentiometric and/or Spectrophotometric Equilibrium Data Using Analytical Derivatives. In Computational Methods for the Determination of Formation Constants; Leggett, D.J., Ed.; Plenum: New York, NY, USA, 1985; pp. 291-352.

37. Gans, P.; Sabatini, A.; Vacca, A. SUPERQUAD: An improved general program for computation of formation constants from potentiometric data. J. Chem. Soc. Dalton Trans. 1985, 6, 1195-1200. [CrossRef]

38. Baes, C.F.; Mesmer, R.E. Iron. In The Hydrolysis of Cations; John Wiley \& Sons: Hoboken, NJ, USA, 1976; pp. 226-237. 
39. Dömötör, O.; Aicher, S.; Schmidlehner, M.; Novak, M.S.; Roller, A.; Jakupec, M.A.; Kandioller, W.; Hartinger, C.G.; Keppler, B.K.; Enyedy, É.A. Antitumor pentamethylcyclopentadienyl rhodium complexes of maltol and allomaltol: synthesis, solution speciation and bioactivity. J. Inorg. Biochem. 2014, 134, 57-65. [CrossRef] [PubMed]

40. Krezel, A.; Bal, W. A formula for correlating $\mathrm{pK}_{\mathrm{a}}$ values determined in $\mathrm{D}_{2} \mathrm{O}$ and $\mathrm{H}_{2} \mathrm{O}$. J. Inorg. Biochem. 2004, 98, 161-166. [CrossRef] [PubMed]

Sample Availability: Samples of the compounds are not available from the authors.

(C) 2019 by the authors. Licensee MDPI, Basel, Switzerland. This article is an open access article distributed under the terms and conditions of the Creative Commons Attribution (CC BY) license (http://creativecommons.org/licenses/by/4.0/). 